Boise State University ScholarWorks

Public Policy and Administration Faculty

Publications and Presentations

Department of Public Policy and Administration

4-1-2012

\title{
Are Telecommuting and Personal Travel Complements or Substitutes?
}

Pengyu Zhu

Boise State University 


\title{
Are Telecommuting and Personal Travel Complements or Substitutes?
}

\section{Pengyu Zhu}

\begin{abstract}
Whether telecommuting and personal travel are complements or substitutes is a key question in urban policy analysis. Using survey responses on telecommuting, previous empirical studies relied on small regional samples and concluded that telecommuting is more likely to function as a substitute for commute travel. These studies also agreed that the substitution effect was small. Using data from the 2001 and 2009 National Household Travel Surveys (NHTS), this study involves two large national samples to try to identify the impact of telecommuting on workers' travel patterns. Through a series of empirical tests, this research investigates how telecommuting influences workers' one-way commute trips, daily total work trips and daily non-work trips, and tries to provide some answers to a question that has been discussed for some years-namely, whether telecommuting and personal travel are complements or substitutes. The results of these tests suggest that telecommuting has been an important factor in shaping personal travel patterns over the 2001-2009 period, and that telecommuting indeed has a complementary effect on not just workers' one-way commute trips but also their daily total work trips and total non-work trips.
\end{abstract}

Keywords: telecommuting; information technology; travel patterns; commute trips; work and non-work trips 


\section{Introduction}

The discussion of whether information and communications technology (ICT) and travel are complements or substitutes has been popular among urban planners and policy makers for some years. The futurist claims generally regard ICT as a substitute for conventional travel as it reduces the desire for face-to-face interaction. Building on Melvin M. Webber's ideas in his series of essays in the 1960s in which he suggested the demise of the traditional city, these futurists generally forecasted the end of traditional cities as improvements in telecommunications eliminates the need for face-to-face interactions, leading to a "placeless society" in which "distance ceases to exist" (e.g., Alvin Toffler 1981; John Naisbitt 1984; Anthony Pascal 1987; Roger Naisbitt 1995; Nicholas Negroponte 1995; William Knoke 1996; and Frances Cairncross 1997).

There is another view that proposes ICT as a complement to travel. Salomon (1986), Niles (1994), Mitchell (2000), and Graham and Marvin (2000) were among the writers to maintain that easier accessibility to IT-based communications will expand the "perceptual space" of individuals and organizations, which in turn generates more physical travel. For example, the visual experience of Paris through television or via the internet could make Paris a more interesting place to visit. The more ICT exposes us to, the greater desire may be to travel to those places for face-to-face interactions (e.g., meeting with clients, friends) or for recreation. Graham and Marvin (2000) asserted that despite some degree of substitutability, the complementarity effect between electronic accessibility and physical travel is dominant. Salomon (1986) and Niles (1994) argued that improvements in ICT may further disperse residential locations which will overall increase vehicle-miles traveled (VMT) as people decide to make additional car trips which will dominate any substitutions for such trips. Similarly, Janelle (1986) argued that 
telecommuters may move further away from their jobs to cheaper and higher-amenity residential locations and, therefore, incur longer (though less frequent) commutes.

It would be ideal to directly analyze the impact of various ICT usages on people's travel patterns. However, ICT is a phenomenon that is hard to measure for empirical analysis. Previous empirical research tended to address this question by analyzing a specialized part of ICT usage-telecommuting. After all, new ICT-based economic activity transformations have boosted the emergence of not just more flexible ("footloose") firms (decentralized locations) but also more flexible workers (telecommuters). Representing a particularly specialized use of ICT, telecommuting is an interesting and relevant modern phenomenon. In recent years, various urban policies have been considered in many large cities/MSAs to address the ever-increasing travel demands and remedy the various travel-related problems such as air quality and traffic congestion. These urban policies (or more specifically, travel demand management programs) include subsidizing transit riding, implementing transit-oriented development, encouraging carpooling, and promoting telecommuting. In terms of telecommuting, many federal, state and county government agencies as well as various private firms have been encouraging their employees to do so, in order to reduce traffic congestion and improve air quality through reduced employee commute trips, as well as to make optimal use of office facilities and equipment while improve overall productivity. In states like California, both state government and county governments already have active telecommuting promotion programs in place ${ }^{1}$. However, whether telecommuting has successfully generated incentives for people to reduce their travel demand remains an open question. Several empirical studies have found that telecommuting has a small substitution effect on commute travel and thus argued that policies promote

\footnotetext{
${ }^{1}$ See "Telecommute incentive plan offered in California" at http://www.accessmylibrary.com/article-1G1-18076748/telecommute-incentive-plan-offered.html. Also see "The San Bernardino County Government Telecommuting Program” at http://www.sbcounty.gov/commuterservices/PDF/Telecommute Policy.pdf.
} 
telecommuting might be promising in this regard. But most empirical studies relied on small samples and only focused on commute travel. Has telecommuting caught on? Has it been a successful planning practice or policy to reduce people's daily travel, which includes both work trips and non-work trips?

The purpose of this study is to provide some new evidence relating to this discussion by empirically investigating the impact of telecommuting on people's travel patterns, using data from the 2001 and 2009 National Household Travel Surveys (NHTS). These are two large national surveys that are spaced over the years that include significant changes in internet availability. In exploring the possible impacts on travel patterns, this study decomposes travel into commute trips, total work trips and various non-work trips. Three specific questions are addressed:

(1) What is the impact of telecommuting on workers' one-way commute trips?

(2) What is the impact of telecommuting on workers' daily total work trips?

(3) What is the impact of telecommuting on workers' daily non-work trips?

In each case, I am interested in any changes between the two survey years. A key issue associated with question (1) is the possibility of endogeneity bias derived from the simultaneous choice of telecommuting and commute distance (or duration) - a worker might choose to commute longer in response to the possibility of telecommuting; or the other way around, longer commute might also motivate the choice to telecommute. Similar to many other empirical studies in which natural experiments ${ }^{2}$ are infeasible, this paper applies an instrumental variables approach to address the endogeneity problem and investigate the causal effect of telecommuting on commute distance/duration.

\footnotetext{
${ }^{2}$ See Ory and Mokhtarian (2006) for an example of using a natural experiment (retrospective survey) to explicitly examine the direction of causality between telecommuting and commute (length and time).
} 
This paper is organized as follows: Section 2 includes a literature review of the impact of telecommuting on travel. Section 3 analyzes the changes in travel patterns from 2001 to 2009 and briefly describes the differences between telecommuters and non-telecommuters in terms of their one-way commute trips, daily total work trips and daily non-work trips. Section 4 discusses the methodology used to test for the above three questions. Section 5 describes the NHTS data and Section 6 summarizes the model results, followed by a discussion of findings in Section 7.

\section{Literature Review}

As a significant part of daily travel as well as an influential factor in residential location decisions, commute trips have been widely studied. Of special interest are comparisons between telecommuters and non-telecommuters. Using various datasets and different methodologies, previous empirical studies have generally agreed that telecommuting is more likely to function as a substitute for commute trips. Some researchers (e.g., Mokhtarian et al. 1995; Gareis 2003; Mokhtarian et al. 2004; Ory and Mokhtarian 2005, 2006; Jiang 2008) have supported the idea that telecommuters live farther from their jobs than non-telecommuters, but the substitution effect of telecommuting prevails because the longer commute distance of telecommuters is offset by the lower frequency and higher speed of these trips.

For example, using data from a survey of 218 California employees (from six state government agencies) over the ten-year period from 1988 to 1998, Mokhtarian et al. (2004) compared, on a quarterly basis, the total commute person-miles traveled by telecommuters and non-telecommuters. They found that one-way commute distances were longer for telecommuters than for non-telecommuters. However, the average quarterly per capita commute person-miles traveled by telecommuters (which consider telecommuting frequency) were generally lower than that traveled by non-telecommuters. These two findings together indicated that telecommuters 
commute infrequently enough to compensate for their longer one-way commutes.

Using the same data on telecommuting and residential and job location changes for the 218 California State government agency employees, Ory and Mokhtarian (2005) supported the findings of Mokhtarian et al. (2004) and focused on the relationships between telecommuting and commute time, distance, and speed. They found that telecommuters have longer commute distances than non-telecommuters, and telecommuters consistently traveled faster than non-telecommuters. As a result of traveling at higher speeds and commuting less frequently, telecommuters on average commute for fewer daily person-miles and person-minutes.

In terms of the size of the travel impact of telecommuting, researchers generally found that this effect is rather small. These studies argued that although telecommuters travel less than non-telecommuters, the overall effect of telecommuting is less significant than we might expect (Hamer et al. 1991; Mokhtarian et al. 1995). For example, based on eight telecommuting pilot programs with a total sample of 382 telecommuters, Mokhtarian et al. (1995) found that commute travel (measured in person-miles) slightly decreased as a result of telecommuting. They also found that noncommute travel decreased slightly as a result of telecommuting as well ${ }^{3}$, and as a result, total travel savings are moderately higher than commute savings alone. In assessing the potential for telecommuting to reduce vehicle-miles travelled (VMT) or total personal-miles, Salomon (1986), Mokhtarian et al. (1995), Handy and Mokhtarian (1995) consistently found that the overall effect of telecommuting is no more than one percent of total household VMT. Similarly, Mokhtarian (1998) used a multiplicative model to forecast the demand for telecommuting and the resulting travel impacts. Her base case used in the forecast suggested that " 6.1 percent of the workforce may be currently telecommuting, with 1.5 percent

\footnotetext{
${ }^{3}$ In the State of California program (73 telecommuters) and the Puget Sound program (63 telecommuters), they found noncommute travel actually slightly decreases as s result of telecommuting; in the Netherlands program (30 telecommuters), they found insignificant change in nonwork travel.
} 
doing so on any given day, eliminating at most one percent of total household vehicle-miles traveled" (p. 215). She suggested the overall substitution effect of telecommuting will "remain relatively flat into the future, even if the amount of telecommuting increases considerably" (p. 215). Mokhtarian et al. (1997) provided similar evidence. More recently, Choo, Mokhtarian and Salomon (2005) conducted a multivariate time series analysis to estimate the impact of telecommuting on total VMT for personal transportation, using aggregate nationwide data. Their results suggested that, from 1988 to 1998 , all telecommuters in the U.S. reduced annual national VMT on the order of 0.8 percent or less.

Most of these studies, however, were based on a relatively small regional sample. Although the surveys were well-designed, such small samples have their limits. Mokhtarian et al. (1995) cautioned that, “.....early, short-term findings from small programs with participants unrepresentative of the population as a whole may change considerably as telecommuting moves into the mainstream" (p. 283). With the 2009 National Household Travel Surveys (NHTS) just recently released, it is now possible to not just conduct a national study but also to contrast with the comparable 2001 NHTS data to identify any temporal changes.

It is also the case that few of the previous studies looked at the impact of telecommuting on non-work trips, with the exception of Mokhtarian et al. (1995) which, based on a total of 382 telecommuters, found a negative or insignificant impact on non-work trips. Any increases in non-work trips due to telecommuting would at least partially offset the substitution effect found in previous research. This research addresses non-work travel in addition to commute trips.

\section{A Preview: Changes in Travel Patterns from 2001 to 2009}

\subsection{Definitions}

For both 2001 and 2009, this study defines telecommuters as those workers who report 
telecommuting (work at home instead of going to usual workplace) at least once a week ${ }^{4}$. Respondents who only work at home (home-based businesses, for example) are not considered as telecommuters. The infrequent telecommuters and those never telecommuting are all classified as non-telecommuters, because I do not expect that infrequent telecommuting (e.g. once a month) would have any sizeable effect on the respondent's residential location choice and thus on his/her commute trips or non-work trips. Thus, non-telecommuters refer to workers who do not telecommute frequently. Non-workers refer to the non-working adults in the household. All telecommuters, non-telecommuters and non-workers can report non-work trips, but only telecommuters and non-telecommuters have commuting trips.

To differentiate this paper from previous research, I decompose travel into work trips and non-work trips. For work trips, I focus on commute trips, because commute trips are the largest and most routine portion of most people's daily work trip. Total daily work trips, which include all daily "to/from work" trips and "work related business" trips, are also discussed. For non-work trips, I decompose them into the types that the NHTS specifies: shopping trips, other family/personal business trips, school/church trips, medical/dental trips, visit friends/relatives trips, and other social/recreational trips.

\subsection{Changes in Travel Patterns}

The main purpose of this paper concerns the differences in travel patterns between telecommuters and non-telecommuters. In order to investigate these differences, a table summarizing the trip data from 2001 and 2009 NHTS is first examined. Table 1 provides summaries for personal one-way commute trips, daily total work trips and total non-work trips, grouped by telecommuting status and work status.

\footnotetext{
${ }^{4}$ The NHTS survey questions on telecommuting were only slightly different between 2001 and 2009 . And in both surveys, respondents who only work at home (e.g. home-based businesses) are skipped in the questions on telecommuting as well as the questions on one-way commute distance and duration. Therefore, my sample only includes those workers who have a workplace away from home.
} 
[Table 1 about here]

One obvious temporal change can be observed in this Table-less frequent daily total work trips and total non-work trips for both telecommuters and non-telecommuters from 2001 to 2009. But the extent of this reduction was different for the two groups, with bigger benefits in terms of less frequent travel seen for telecommuters ${ }^{5}$. Given the reduction in frequency, what happened to distance and duration?

For commute trips, telecommuters' one-way commute distance and duration both significantly increased from 2001 to 2009. Non-telecommuters' one-way commute showed a similar trend from 2001 to 2009 , but to a much lower extent than that of telecommuters. For total work trips, telecommuters' average one-day total work trip distance and duration were also significantly longer in 2009 compared with 2001, even though these trips were less frequent on any given day in 2009. Non-telecommuters' average one-day total work trip distance and duration only slightly increased from 2001 to 2009. These findings imply that telecommuters' daily total work trip frequency has significantly decreased over the years, but the increase in the distance of these work trips has outweighed the decrease in frequency, and that for non-telecommuters, their daily total work trip distance, duration and frequency were all less changed. For total non-work trips, telecommuters' average one-day total non-work trip distance and duration both significantly decreased from 2001 to 2009 , as a result of the decrease in non-work trip frequency. Meanwhile, non-telecommuters' average one-day total non-work trip distance, duration and frequency also decreased (in a slightly smaller amount than telecommuters) from 2001 to 2009.

All these findings suggest that increased information technology usage (telecommuting,

\footnotetext{
${ }^{5}$ Telecommuters' average daily total work trip frequency reduced $10.1 \%$ from 2001 to 2009; non-work trip frequency reduced $4.8 \%$. Non-telecommuter's average daily total work trip frequency and daily total non-work trip frequency reduced $2.0 \%$ and $2.6 \%$, respectively.
} 
online shopping, online banking, etc.) over these years might have allowed workers to take fewer (or, less frequent) trips over time, but many of them chose locations with longer work trips and generally shorter non-work trips And these temporal changes were more pronounced for telecommuters. To be sure, there are other possible reasons for differences in travel behavior over time. In particular, the deep economic recession experienced in 2008 and 2009 could be an explanation for fewer trips (lower incomes, less business activity) and longer commute distances (need to look farther from home to find a job; or, just the selection bias that those employed in 2009 are less likely to be temporary or lower-skilled workers, whose jobs would have been closer to home than those of professional or higher-skilled workers). Nevertheless, the reduced (work and non-work) trip frequency benefits in 2009 were greater for the telecommuters.

Interestingly, the temporal comparisons of the one-way commute trips, the mean one-day total work trips and total non-work trips between 2001 and 2009 show that the daily total travel distance and duration (which is the sum of the daily total work trips and total non-work trips) remained remarkably stable over this period, for both telecommuters and non-telecommuters. This provides evidence in support of the fixed travel budget hypothesis of Zahavi (1979, 1980a, 1980b), in which he argued that there is a "travel time budget" which limits people's commute time, activity time and the subsequently induced non-work travel time, and that this travel-time budget is somewhat constant over time.

Most importantly, in both 2001 and 2009, telecommuters were consistently engaging in more frequent and significantly longer total work trips and total non-work trips than non-telecommuters on any given day. In 2001, telecommuters' average daily total work trips was 34.2 percent longer in distance, 26.9 percent longer in duration, and 14.7 percent more frequent than that of non-telecommuters; telecommuters' average daily total non-work trips was 17.1 
percent longer in distance, 17.4 percent longer in duration, and 13.3 percent more frequent than that of non-telecommuters. In 2009, those numbers changed to 43.3 percent, 32.5 percent, 5.2 percent for daily total work trips and 15.7 percent, 14.3 percent, 10.7 percent for daily total non-work trips, respectively. Even though both telecommuters and non-telecommuters are found to have a quite stable "travel budget" over time, telecommuters appear to have a significantly larger travel "budget" than non-telecommuters. This supports the idea of complementarity between telecommuting and personal travel.

As already discussed, many factors affect people's travel patterns. Is this larger "travel budget" of telecommuters a direct outcome of their telecommuting status? Or is it because of those unobserved factors (such as place of residence, age, gender, income, etc.) that are not fully controlled in the previous table? To address these questions, I estimate various models to more fully investigate the impact of telecommuting on people's travel patterns.

\section{Research Methodology}

In order to fully understand travel patterns in light of the impact of a telecommuting status, I compare the one-way commute distance and duration between telecommuters and non-telecommuters. I also investigate their daily total work trips and various non-work trips.

\subsection{Model specification and variables}

To better understand the factors affecting people's travel behavior, I start with the concept of travel demand. Travel demand is generally associated with the activity patterns of individuals or households. In this context, travel demand can be understood from the perspective of activity-based approaches. Activity-based approaches "study travel in the context of daily household activity patterns, as a link in the process of fulfilling travel demands through the formation of daily sets, or chains, of activities" (Fox 1995, p.105). Using this approach, 
researchers generally attributed travel demand to socioeconomic status, demographic factors including household structure and lifecycle (Strathman, Dueker and Davis 1994; Srinivasan and Ferreira 2002), and lifestyle (Nelson and Niles 2000).

In addition, the place of residence is also an important determinant of travel behavior. The travel behavior of people living in suburbs could significantly differ from those living in urbanized areas. Results shown in the Appendix 1 do suggest that average distances and durations of commute trips and non-work trips were significantly longer for suburban residents in both 2001 and 2009.

Based on this reasoning, the explanatory variables in the models that follow include individual demographic characteristics (gender, age, education, occupation), household socioeconomic characteristics (presence of child, household income), locational attributes (MSA size, place of residence in urbanized area, suburban area or rural area), and transportation characteristics (number of vehicles per driver, transportation mode). The variable of interest - telecommuting — is added to the models as a transportation characteristic variable. The basic models rely on ordinary least squares (OLS), but are subject to modifications as required and discussed later. The basic model is specified as the following equation:

Trip Distance/Duration (log) $=f$ (vector of demographic and socioeconomic characteristics, vector of locational attributes, vector of transportation factors, telecommuting dummy)

\subsection{Studying the impact of telecommuting on workers' one-way commute distance and duration}

As previous studies on telecommuting have focused on commute trips, it makes sense to start the discussion by analyzing the impact of telecommuting on worker's commute distance 
and duration. The basic OLS models test for the effects of differences in worker's demographic characteristics, household socioeconomic and locational attributes and determine the importance of telecommuting on workers' one-way commute distance and duration.

To be sure, there may be an endogeneity problem associated with the telecommuting variable. A worker's choice to telecommute is endogenous to commute distance or duration. It is possible that a worker chooses to commute longer in response to the possibility of telecommuting; however, the opposite case also seems reasonable, that people with longer commutes are more willing to telecommute to avoid lengthy commutes. In order to address this endogeneity problem, I test a Two-Stage Least Squares (2SLS) model by adding instrumental variables to instrument the telecommuting variable. The instrumental variables used in the 2001 2SLS models are internet use at home (dummy) and total number of phones available. Due to the fact that the 2009 NHTS included a slightly changed questionnaire on internet usage, I do not have these two variables for that year. Instead, I use "frequently use internet" (dummy) as the instrumental variable in the 2009 2SLS models. These instrumental variables affect worker's likelihood of telecommuting but do not directly affect his/her commute distance or duration.

The choice of commute mode is also endogenous to the commute distance/duration. Arguably mode is more problematic than telecommuting in this respect: given the conventional hierarchy that residential location is a long-term decision while auto ownership and mode choice are medium- and short-term decisions, one might expect mode choice to be a consequence of commute distance, not a cause of it. For example, people (for the most part) don't commute shorter distances because they walk; rather they walk to work if their commute distance is short enough. Duration is a little bit trickier, in that it is partly a consequence of mode choice (given distance), but it could still affect the mode choice. If not carefully instrumented for, the 
endogenous commute mode variables in the model would bias the coefficient estimates. Realizing that workers using public transit or other modes (walking, bicycling) to commute only accounted for a small percentage of the full sample of workers in both 2001 and $2009^{6}$, I restrict the final sample in this section to be workers commuting by personal vehicles only.

\subsection{Studying the impact of telecommuting on workers' daily total work trips}

The previous arguments in the academic literature on "telecommuting substitutes for conventional travel" were based on the fact that telecommuters do not have to commute on days they work at home. Therefore, an ideal way to accurately measure the impact of telecommuting on commute trips would be comparing the weekly or monthly total commute distance and duration between telecommuters and non-telecommuters. However, due to the limitations of NHTS surveys, accurate data were not available on the number of days a respondent telecommutes and the number of days he/she goes to workplace on a weekly or monthly base for both 2001 and $2009 \mathrm{NHTS}^{7}$, and thus the tests in Section 4.2 focus on one-way commute distance and duration only.

While I believe previous tests on workers' one-way commute distance and duration illuminate, to some extent, the impact of telecommuting on travel patterns, both 2001 and 2009 NHTS also collected day-trip diaries from a subset of respondents which recorded all the details of their one-day trips. This makes it possible to compare the one-day total work trips and total non-work trips between telecommuters and non-telecommuters. My hypothesis is that

\footnotetext{
${ }^{6}$ In 2001, 92.4\% workers commuted by personal vehicles, $4.0 \%$ commuted by public transit, $3.7 \%$ commuted using other mode. In $2009,94.0 \%$ workers commuted by personal vehicles, $2.5 \%$ commuted by public transit, $3.5 \%$ commuted using other mode. 7 Although 2001 NHTS did not have data on the detailed monthly frequency of telecommuting, 2009 NHTS did ask "How many times in the last month did you work only at home for an entire work day instead of traveling to your usual workplace?" The answers to this question show that 3\% telecommuters telecommuted over 5 times a week (more than 20 times a month). Using five workdays per week as the default number for all workers and truncating those who telecommuted over 20 days in a month to 20 days (on the argument that weekday travel is what we are interested in from a congestion-reduction standpoint), a simple simulation shows that the average monthly commute (round-trip commute distance multiplied by days of commute within the month) of telecommuters is insignificantly different from that of non-telecommuters in 2009. But in terms of methodology, this simple simulation of monthly total commute is less rigorous than the tests I conducted on the one-way commute trips.
} 
telecommuters may have more other work-related trips and/or non-work trips on days they work at home and thus telecommuting still has a positive impact on daily total work trips and non-work trips.

This section focuses on the one-day total work trips and tries to test how the status of telecommuting affects workers' one-day total work trips. I use the NHTS day-trip dataset to calculate the trip day total work trip distance, duration and frequency for each worker in the sample. Since one-day total work trips are the sum of all "to/from work" trips and "work-related business" trips, the endogeneity problem associated with the telecommuting variable is less in this case ${ }^{8}$. Therefore, I simply estimate multivariate OLS regressions ${ }^{9}$ to study the impacts of telecommuting on the distance, duration and frequency of daily total work trips ${ }^{10}$. The multivariate regression models can be expressed via the following equation:

Vector of daily total work trip distance, duration and frequency $(\log )=f$ (vector of demographic and socioeconomic characteristics, vector of locational attributes, vector of transportation factors, weekend dummy, telecommuting dummy)

I use the same set of control variables as in the previous models to account for the individual and household socioeconomic characteristics, household locational attributes and transportation factors. In addition, I add a dummy variable to indicate whether the trip day is a weekend. The telecommuting variable is a dummy variable indicating whether the worker is a telecommuter.

\subsection{Studying the impact of telecommuting on workers' daily non-work trips}

Another important part of this study is an analysis of the impacts of telecommuting on

\footnotetext{
${ }^{8}$ For the daily total work trip models in both 2001 and 2009, Durbin-Wu-Hausman chi-sq test and the "difference-in-Sargan" or $\mathrm{C}$ test failed to reject the null hypothesis that the specified endogenous regressor (telecommuting) can be treated as exogenous.

${ }^{9}$ Following the naming convention, multiple regression refers to regression models with a single dependent variable and two or more predictor variables. By contrast, multivariate regression has multiple dependent variables, and any number of predictors. The advantage of multivariate regression lies in the increase in efficiency gained by allowing the error terms of the multiple equations to be correlated.

${ }^{10}$ For those who still concern the endogeneity problem in this case, I also estimated 2SLS models using the same instrumental variables as in previous commute trip models. The results of 2SLS are comparable to those of OLS for daily total work trips.
} 
workers' non-work trips. I use the NHTS day-trip dataset to calculate the trip day total trip distance, total trip duration, and total trip frequency of each non-work trip category for each worker in the sample. Since non-work trip distance, duration and frequency will not directly affect workers' likelihood to telecommute, there is arguably no endogeneity problem associated with the telecommuting variable in this case. Therefore, similar multivariate OLS regression models to those in section 4.3 are used to study the impacts of telecommuting on the distance, duration and frequency of each type of non-work trips as well as daily total non-work trips. They can be expressed via the following equation:

Vector of non-work trip distance, duration and frequency $(\log )=f$ (vector of demographic and socioeconomic characteristics, vector of locational attributes, vector of transportation factors, weekend dummy, telecommuting dummy)

I use the same set of control variables as in the previous models and a "weekend" dummy variable is also added. The telecommuting variable used is a dummy variable indicating whether the worker is a telecommuter. To avoid the endogeneity problem associated with transportation mode choice (similar to the discussion in 4.2), the final sample in both 4.3 and 4.4 are also restricted to workers who only use personal vehicles for their work trips and non-work trips.

\section{Data and Descriptive Statistics}

The primary dataset for this research is the 2001 and 2009 National Household Travel Surveys (NHTS). The NHTS is the only available large-sample national data set that simultaneously includes information on characteristics and location of households and people, detailed information on commute trips, daily total work trips and all kinds of non-work trips, and the status of telecommuting and internet usage. Comparisons between the 2001 data and 2009 data are made to explore the impacts of telecommuting over time. After all, the impact of 
telecommuting on travel patterns is not just a case of cross-sectional variability but also an inter-temporal one. With a detailed inter-temporal comparison, a more accurate and detailed assessment of these impacts can be identified.

In 2001, of all respondents who answered the question of whether they worked from home instead of traveling to their usual workplace on any day in the past two months, 91.7 percent of respondents said they did not telecommute in the past two months, 3.7 percent of respondents telecommuted infrequently (less than once a week), 4.6 percent of respondents telecommuted frequently (at least once a week). In 2009, of all respondents who answered the question of whether they had the option of working at home instead of going into their workplace, 85.9 percent of respondents said they did not have the option to telecommute, 5.3 percent of respondents had the option but did not telecommute in the last month, 4.2 percent of respondents reported they telecommuted infrequently (at least once but less than four times in the last month), 4.6 percent of respondents telecommuted frequently (four times or more in the last month). So, the percent of telecommuters (including frequent and infrequent telecommuters) only increased slightly (from 8.3 percent to 8.8 percent) over the $2001-2009$ period $^{11}$. Using the suggested definition for telecommuter in this paper (that is, telecommute at least once a week), 4.6 percent of respondents were telecommuters in both 2001 and 2009.

This research decomposes personal travel patterns into commute trips, daily total work trips and daily non-work trips. Commute trips are measured in terms of one-way commute distance and duration. Daily total work trips are measured in one-day total work trip distance, duration and frequency for each worker in his/her trip day. Daily non-work trips are measured in total one-day trip distance, duration and frequency by trip type for each worker in his/her trip

\footnotetext{
11 The slight increase in the percent of telecommuters may be partly due to an increase in information technology availability, and may be partly due to a disproportionate decrease in employment among non-telecommuters during the 2008-2009 economic recession (i.e. construction workers and others hard-hit by the recession are less likely to be candidates for telecommuting).
} 
day $^{12}$. Table 2 provides summaries for workers' commute trips and daily non-work trips ${ }^{13}$, grouped by place of residence.

[Table 2 about here]

For workers' commute trips and various non-work trips, I use (two-tailed) t-tests to compare the means in four spatial/temporal comparison pairs (urban 2001 vs. suburban 2001, urban 2009 vs. suburban 2009, urban 2001 vs. urban 2009, suburban 2001 vs. suburban 2009). The results of these t-tests are reported in Appendix 1. The differences in travel patterns between urban residents and suburban residents are first tested for both years. In 2001, the distances of one-way commute trips and various daily non-work trips were significantly longer for workers living in suburban areas, compared with those living in urbanized areas. But the durations of all these trips were only slightly longer (some of them were statistically insignificant) for workers living in suburban areas. However, in 2009, both distances and durations of one-way commute trips and various daily non-work trips were significantly longer for suburbanites than for urbanites. This change suggests that the longer trip distance in suburban areas was somewhat offset by higher travel speeds in 2001, but this was seemingly no longer the case in 2009 as traffic congestion had become worse. In addition, part of the effect could have been people choosing to trade off more distant residential locations that offer lower priced housing over the 2001-2009 period. In line with the conventional view that suburbanites do less interacting with others than urbanites, the average frequencies of several types of non-work trips made by workers living in suburban areas are found to be statistically significantly lower than those made

\footnotetext{
${ }^{12}$ One-way distance or duration is certainly a better and more straightforward measure for commute trips. But for the different non-work trip types, respondents of the trip diary may report combining different trip purposes in one trip (trip chaining), and they may have multiple shopping/recreational/school/friend trips during the trip day. This makes it very hard, if not impossible, to disentangle the one-way trip distance and duration for all their different non-work trip types. Moreover, since we are interested in the impact of telecommuting on travel patterns, total trip distance and duration for each non-work trip type would be better measures than one-way trip distance and duration.

${ }^{13}$ Daily total work trips are not included, since their patterns are similar to commute trips. This is not surprising because commute trips are the major parts of daily total work trips for most workers. Also note that the sample in this table includes all workers, not just those who commute or travel via personal vehicles.
} 
by workers living in urbanized area, and these were true for both 2001 and 2009. But it should be added that the differences in frequencies are too small to denote real lifestyle differences between the two groups.

The temporal changes in travel patterns over the 2001-2009 period are also highlighted for workers living in urbanized areas and workers living in suburban areas separately. For workers living in urbanized areas, one-way commute trips had longer (statistically significant) distance and duration in 2009 than in 2001, while daily total non-work trips had slightly shorter (statistically significant) distance, duration and frequency in 2009. When decomposing their total non-work trips into various types of non-work trips, I find shopping trips and other social/recreational trips had slightly shorter (statistically significant) distance and duration in 2009 than in 2001, while school/church trips experienced slightly longer (statistically significant) distance and duration in 2009. For workers living in suburban areas, the distance and duration of one-way commute trips were longer (statistically significant) in 2009 than in 2001, while daily total non-work trips had the distance and frequency slightly decreased from 2001 to 2009 (the mean difference of daily total non-work trip durations between the years was statistically insignificant). When looking into the various types of non-work trips made by workers living in suburban areas, I find the distance, duration and frequency of almost all non-work trip types were insignificantly different between 2001 and 2009 .

These different measures of various trips are used in the empirical models as dependent variables. The models also include a set of explanatory variables to account for the individual demographic characteristics, household socioeconomic and locational attributes, and transportation characteristics. Summary statistics of the explanatory variables used in the analyses are presented in Table 3. 
[Table 3 about here]

\section{Model Results}

\subsection{Workers' One-way Commute Distance and Duration}

\subsubsection{OLS models}

As a starting point, I estimate OLS models to account for differences in workers' demographic characteristics, household socioeconomic and locational attributes and test the importance of telecommuting on workers' commute distance and duration. Models (1) and (2) in Table 4 present OLS results for 2001, while Models (5) and (6) report OLS results for 2009.

[Table 4 about here]

Of particular interest to this study is the role of a telecommuting status in affecting workers' commute distance and duration. The simple OLS models show different results for 2001 and 2009. Although the 2009 OLS models show a significant positive impact of telecommuting on workers' one-way commute distance and commute duration, the 2001 OLS models show insignificant impacts. As discussed in the previous section, it is possible that an endogeneity problem is associated with the telecommuting variable. In fact, the Wu-Hausman F test, Durbin-Wu-Hausman chi-sq test, and the $\mathrm{C}$ or "difference-in-Sargan" test all suggest rejecting the null hypothesis that the specified endogenous regressor (telecommuting in this case) can actually be treated as exogenous. Therefore, I test Two-Stage Least Square (2SLS) models in the next section to address the endogeneity problem.

Among workers' demographic characteristics, younger workers and male workers consistently reported significantly longer one-way commute distances and commute durations, whereas medical condition was insignificant in all four models. I also consistently find that workers with higher education had significantly longer commute distances and durations. With 
respect to the occupation variables, the currently released version of the 2009 NHTS data does not include the occupation under which the respondent's job falls ${ }^{14}$. In order to make inter-temporal comparisons between the 2001 and 2009 models, I drop the occupation variables in all the 2001 models (including those discussed in later sections) ${ }^{15}$. The 2001 models with occupation variables added are separately reported in the Appendix 2 to this $\operatorname{paper}^{16}$.

Among household socioeconomic attributes, workers from households with children tended to have longer one-way commute distance and durations in both 2001 and 2009. Longer commutes are also found to be associated with higher household total income and greater number of vehicles per driver. Among household location characteristics, workers residing in the suburbs (omitted category in the models) tended to have longer one-way commute distances and durations than those living in urbanized areas or rural areas in both years. I also see a consistent pattern that both commute distance and duration increased with the size of MSA in 2001 and 2009.

\subsubsection{SLS models}

Models (3) and (4) in Table 4 present 2SLS results for 2001, while Models (7) and (8) report 2SLS results for 2009. The instruments used in the 2001 2SLS models are "internet use at home" (dummy) and "total number of phones". The instrument used in the 2009 2SLS models is "frequently use internet" (dummy). Since weak or invalid instruments can result in measurement error in the endogenous regressor (see Bound et al. 1995; Hall et al. 1996; Greene 1997; Staiger

\footnotetext{
${ }^{14}$ Similar to 2001 NHTS, the 2009 NHTS also classified the subjects' occupations into five categories in their interview questionnaire: 1) Sales or service; 2) Clerical or administrative support; 3) Manufacturing, construction, maintenance, or farming; 4) Professional, managerial, or technical; 5) Other occupations. Since it is a relatively new dataset, the current version of 2009 NHTS data does not include the occupation variable. As soon as it is available, it will be included in future version of this paper. ${ }^{15}$ Simple robustness test comparing the 2001 models with and without the occupation variables reveal that dropping the occupation variables does not affect the coefficient estimates for other variables or model fitness in any significant ways. ${ }_{16}$ Based on Model (1)-(4) (using 2001 data) in appendix 2, it appears that workers report the longer commute distance and duration if employed in the categories of "manufacturing, construction, maintenance, or farming" (omitted category in our models) or in the category of "professional, managerial, or technical", while those working in the category of "sales or service" tend to have the shortest commute distance and duration.
} 
and Stock 1997), several tests are conducted on the relevance of these instruments after I run the first stage regression for both 2001 and 2009. First, the simple t-statistic and F-statistic from the first stage regression both show that these instruments are statistically significant. The F-statistic is a sufficiently well-accepted simple tool used to infer the weakness of instruments, and a common rule of thumb suggests that if $F>10$ then one can treat the instruments as sufficiently strong and the usual 2SLS output can be accepted (Stock 2010). Secondly, IV redundancy test (LM test of redundancy of specified instruments) shows that neither of these instruments is redundant. Thirdly, the Bound-Jaeger-Baker F statistics (see Bound et al., 1995) and "partial $\mathrm{R}^{2 \text { ", }}$ measures (see Shea 1997) all suggest these instruments are relevant. For example, partial R-squared of the instruments accounts for a very high percentage of the total R-squared (42.2 percent for 2001 and 23.1 percent for 2009).

The above tests suggest that the 2SLS models are able to address the endogeneity problem and provide more plausible coefficient estimates for the instrumented telecommuting variable ${ }^{17}$. Comparing the OLS models and 2SLS models for both 2001 and 2009, I see that no variables, except the telecommuting variable, have significantly changed in terms of their coefficient estimates. The coefficient estimates for the telecommuting variable in all the 2SLS models are statistically significant and have increased in magnitude compared with those of the OLS models. For example in Model (3), the impact of telecommuting on commute distance has become statistically significant, with its coefficient changed from 0.004 in the previous OLS model (Model 1) to 1.182 in the 2SLS model (Model 3).

Comparing the size effect of telecommuting on commute duration versus commute distance, I find that in both years the (positive) effect on commute duration was only one third of

\footnotetext{
${ }^{17}$ As corroboration I also used limited information maximum likelihood (LIML) estimation method in a two-stage context. LIML estimation method usually has better performance than 2SLS when instruments are weak (Stock 2010). The results of LIML are very similar to 2SLS and 2SGMM for both years.
} 
the effect on commute distance (note that the relations are both in the semi-log form). This may have to do with the fact that telecommuters, although living farther from their workplace than non-telecommuters, could more freely choose a residential location and routes that reduce the congestion experienced. This result is somewhat in line with other earlier research that found telecommuters experienced longer commute distances but not commute durations as telecommuters may have traveled faster than non-telecommuters (e.g. Ory and Mokhtarian 2005).

Since I estimate the same models for 2001 and 2009, it is possible to compare the impact of telecommuting on workers' one-way commute distance and duration over the years. In terms of the impact of telecommuting on one-way commute distance, the 2SLS models show that the coefficient estimates for telecommuting changed from 1.182 in 2001 (Model 3) to 2.819 in 2009 (Model 7)—more than twice the effect. In terms of the impact of telecommuting on one-way commute duration, 2SLS models show that the coefficient estimates for telecommuting changed from 0.337 in 2001 (Model 4) to 0.993 in 2009 (Model 8). These results indicate that the sizes of the impacts have increased over the years, suggesting that those workers who exercise a telecommuting option have chosen to live further away from their place of work (in terms of distance as well as duration) over this time period.

\subsubsection{Other Two-Stage Models}

Since the endogenous regressor (telecommuting) is binary, the 2SLS model applies a linear probability model in the first stage. A well-known problem of a linear probability model is that its forecasts do not necessarily fall into the $(0,1)$ interval. But nevertheless it has been suggested as a simple alternative specification when endogenous explanatory variables are binary, since 2SLS estimators are usually consistent and computationally attractive (see Heckman and 
MaCurdy 1985). Another disadvantage of the linear probability model is that it often suffers heteroscedasticity problem. In fact, the Pagan-Hall test (see Pagan and Hall 1983) suggests the presence of heteroscedasticity in the 2SLS models for both years. To address these issues, two additional models are used to compare the results-Two-Stage Generalized Method of Moments (2SGMM) model is used to correct for heteroscedasticity; Two-Stage Probit Least Squares (2SPLS) model is used to apply probit model in the first stage ${ }^{18}$.

The results of 2SGMM models and 2SPLS models for 2001 and 2009 are reported in Appendix 3. The coefficient estimates of the telecommuting variable in 2SGMM models are very similar to those in the 2SLS models, while those in the 2SPLS models are slightly smaller in magnitude. All other variables have very similar coefficient estimates across the models. The comparison of the results of these three models suggests that the previous findings about the impact of telecommuting on commute distance/duration are consistent across different model specifications.

\subsection{Worker's Daily Total Work Trips}

This paper also investigates worker's daily total work trips as a supplement to the study of their one-way commute trips. This section uses multivariate OLS regression models to test how the status of telecommuting affects workers' one-day total work trip distance, duration, and frequency. Table 5 presents the multivariate regression results for workers' daily total work trips in 2001 and $2009^{19}$.

[Table 5 about here]

For all six models, all coefficient estimates of the control variables are consistent with the previous results or the same as expected. Older workers had shorter (in terms of total trip

\footnotetext{
${ }^{18}$ For all three models, when using the predicted probability of telecommuting in the second-stage OLS regression, the standard errors are corrected to ensure accurate inferences on the significance of coefficients.

19 The sample is restricted to workers who only used personal vehicles in these work trips.
} 
distance and duration) and fewer (in terms of trip frequency) daily work trips in both 2001 and 2009. Male workers and highly educated workers consistently had longer (in terms of total trip distance and duration) and more frequent daily work trips. Medical condition had a negative impact on daily total work trips in terms of total trip distance, duration and frequency. Residents of urbanized areas had shorter (in terms of total trip distance and duration) but more frequent daily work trips, compared with suburban residents. MSA size also consistently had a significantly positive impact on daily total work trip distance and duration but a negative impact on frequency. As expected, people had less work trips (in terms of distance, duration and frequency) on weekends.

The variable of interest—-the telecommuting dummy variable—had a positive impact on daily total work trips in terms of distance, duration and frequency in both 2001 and 2009. Note that the effects of telecommuting on daily total work trip distance and duration in 2009 were twice as much as in 2001. But the impact on daily work trip frequency decreased significantly over the years. This suggests that telecommuters consistently had more frequent daily work trips than non-telecommuters, but this positive impact of telecommuting on trip frequency has decreased over time. Moreover, the increase in the distance and duration of these work trips has outweighed the decrease in frequency, and therefore, the positive impact of telecommuting on daily total work trip distance and duration has become even larger from 2001 to 2009.

\subsection{Worker's Daily Non-work Trips}

Another important part of this research is to analyze the impact of telecommuting on workers' non-work trips. That is, how do telecommuters' non-work trips differ from those of non-telecommuters. Multivariate regression models are estimated to simultaneously test total trip distance, total trip duration, and total trip frequency of each non-work trip category for each 
worker in the sample ${ }^{20}$. The same set of variables is used to control for the individual and household socioeconomic characteristics, household locational attributes, etc. In addition, I add a dummy variable to indicate whether the trip day is a weekend. Models (1) and (2) of Table 6 present the multivariate regression results for workers' non-work trips (by trip types) in 2001 and 2009. Only the coefficient estimates (and t-values) for the telecommuting variables are reported in Table 6 in order to keep the table simple. Detailed regression results are available on request.

[Table 6 about here]

For both Models (1) and (2), all coefficient estimates of the control variables are consistent with the previous results or the same as expected. Older workers had shorter (in terms of trip distance and duration) and fewer (in terms of trip frequency) trips in almost every trip category. Male workers consistently had longer (in terms of trip distance and duration) and more frequent "visit friends/relatives" trips and "other social/recreational" trips. Medical condition had a negative impact on almost any non-work trip types in terms of total trip distance, duration and frequency. Highly educated workers had longer (in terms of trip distance and duration) and more frequent "visit friends/relatives" trips and "other social/recreational" trips but had shorter and less frequent "shopping" trips. Living in a larger MSA resulted in longer non-work trip distance and duration, but the frequency of most non-work trip categories was generally unrelated to MSA size. Compared with suburban residents, living in an urbanized area involved shorter trip distance and duration but higher trip frequency for almost all non-work trip types (e.g. shopping trips, visit friends/relatives trips, other social recreational trips). "Weekend" had a negative effect on "medical dental" trips but had a positive effect on almost all other non-work trips (such as shopping trips, other social recreational trips), in terms of trip distance, duration and frequency.

The variable of interest—-the telecommuting dummy variable — had a positive impact on a

\footnotetext{
${ }^{20}$ The sample is restricted to workers who only used personal vehicles in these non-work trips.
} 
majority of non-work trip types in terms of trip distance, duration and frequency in 2001 and 2009. This positive impact was (statistically) significant for "shopping" trips and "other family/personal business" trips in 2001, and was (statistically) significant for "shopping" trips, "other family/personal business" trips, and "other social/recreational" trips in 2009. When adding all types of non-work trips together, I find that telecommuting had a significantly positive impact on the worker's daily total non-work trip distance, duration and frequency in both years. Note that the positive effects of telecommuting on daily total non-work trip distance, duration and frequency have all slightly decreased over the 2001-2009 period. This suggests telecommuting is having a weaker (positive) effect on workers' daily total non-work trips over time, as opposed to a stronger effect on daily total work trips over time found in Section 6.2. As a result, although telecommuters have been found to have significantly longer daily total work trips as well as longer total non-work trips than non-telecommuters after holding constant other factors (such as age, gender, place of residence, etc.), the differences in the daily total non-work trips (in all three measures) between telecommuters and non-telecommuters are expected to gradually shrink over time, while the differences in daily total work trips (in terms of distance and duration only, not frequency) are expected to widen.

\section{Conclusions}

Based on two large national samples, results from this research shed some light on personal travel patterns and how they changed over the years. The research also highlights how individual and household socioeconomic characteristics and household locational attributes affect people's travel patterns. Most importantly, through a series of empirical tests, this research suggests that telecommuting has been a consistently important factor in shaping personal travel patterns over the 2001-2009 period, and that telecommuting indeed has a complementary effect 
on not just workers' one-way commute trips but also their daily total work trips and total non-work trips. As expected, these effects are found to be more profound in 2009 than in 2001.

Using instrumental variables to address the endogeneity problem associated with telecommuting, the 2SLS tests (and other two-stage models) show that telecommuters are able to choose lifestyles involving longer one-way commute distances and durations than non-telecommuters, other thing being equal (such as place of residence, age, gender, etc.). And the size of the effect of telecommuting was roughly three times as large in 2009 as in 2001, suggesting that telecommuters have chosen to live further away from their places of work (in terms of distance as well as duration) over this time period.

In addition, I also test the impact of telecommuting on workers' one-day total work trips (including all to/from work trips and all work-related business trips). I find telecommuting had a significantly positive impact on the one-day total work trips in both years, in terms of all three measures (trip distance, duration, and frequency). As for temporal changes, the positive impact of telecommuting on one-day total work trip distance and duration has doubled from 2001 to 2009, while the positive impact on frequency has decreased. These results suggest that telecommuters' lifestyle differs from non-telecommuters in significant ways with respect to their daily total work trips: 1) Holding constant various factors such as age, gender, place of residence, travel mode, etc., telecommuters consistently have more frequent daily work trips than non-telecommuters, although this difference in work trip frequency between the two groups has been falling over the past eight years. 2) Holding constant other factors, telecommuters consistently have longer (distance and duration) daily total work trips than non-telecommuters, and these differences in total work trip distance and duration between the two groups have been enlarging over the past eight years. 
This research also examined workers' daily total non-work trips. I find that telecommuting had a significantly positive impact on workers' one-day total non-work trip distance, duration and frequency in both 2001 and 2009. But the sizes of all these effects are found to be slightly decreasing over the 2001-2009 period. These results suggest that telecommuters' lifestyle also differs from non-telecommuters in terms of their daily total non-work trips-holding constant various other factors, telecommuters consistently have longer and more frequent daily total non-work trips than non-telecommuters, although the differences (in all three measures) between the two groups have slightly diminished over the past eight years. After further decomposing workers' non-work trips into different categories, it appears that telecommuting has a positive impact on workers' many different non-work trip types (in terms of trip distance, duration and frequency $)^{21}$.

It is also worth noting that the 2001 vs. 2009 difference tests show that workers' travel patterns in general have indeed changed over time. For both telecommuters and non-telecommuters, the 2001-2009 increase in the distance and duration of one-way commute trips and daily total work trips has been somewhat offset by the decrease in daily total non-work trips, and thus a stable "travel budget" has been observed over time for both groups. However, the facts that telecommuters have been found to have longer one-way commute trips, longer and more frequent daily total work trips and total non-work trips than non-telecommuters in both 2001 and 2009 indicate that telecommuters consistently have a significantly larger "travel budget" than non-telecommuters.

Incurring not just longer one-way commute trips but also longer and more frequent daily

\footnotetext{
${ }^{21}$ Note that the trip diary used by NHTS only records respondent's one-day trips. And the day of the trip diary could very possibly not be the day of telecommuting for some telecommuters. Therefore, the day trip data provided in 2001 and 2009 NHTS have the potential to underestimate the impact of telecommuting on the telecommuters' non-work trips. If a dataset containing people's trip diaries that cover a longer period of time was used, we would expect an even larger impact of telecommuting on the workers' non-work trips.
} 
total work trips and total non-work trips, the complementary effect of telecommuting on personal travel is indeed significant. Therefore, telecommuting might not be an effective planning practice or policy to reduce traditional travels. As technological progress continues to unfold and more people become able to telecommute, we may expect the current trend in the increase of travel demand to continue into the future. The hopes of planners and policy makers who expected the promotion of telecommuting programs to substitute for face-to-face interactions and thus reduce traditional travels remains largely unmet. To better plan for cities of the future, more realistic transportation policies should be considered to address the ever-increasing travel demands and remedy the various travel-related problems such as air quality and traffic congestion. At a time of concern over the emissions of greenhouse gases, it appears that telecommuting is not (yet) a simple antidote. Instead, people seem to simply reallocate their travel budgets.

To be sure, the approaches applied in this research have some limitations. First, someone might have concerns on the low R-squared of the models. But it is certainly not out of line for disaggregate travel behavior models. Second, although the robustness test shows that dropping worker's occupation in 2001 models neither significantly changes the model goodness-of-fit nor the coefficient estimates, future research would still be better-off by including this variable when new version of 2009 NHTS is released. Finally, as part of the focus of this study, the causal effect of telecommuting on commute distance is estimated via the instrumental variables method, but nothing can be concluded about the opposite direction of causality-longer commute distance promotes more telecommuting. In future work, I will attempt a real structural equations model in future research, in which each endogenous variable (commute distance and telecommuting) is both a cause and effect of the other. I hope to identify the equations system and provide insights into direct versus total effects, which direction of causality is stronger, and so on. 


\section{Acknowledgments}

The author would like to thank Peter Gordon for the valuable suggestions and comments.

\section{References}

Bound J, Jaeger DA, Baker RM (1995) Problems with instrumental variables estimation when the correlation between the instruments and the endogenous explanatory variable is weak. Journal of the American Statistical Association 90(430):443-450

Cairncross F (1997) The death of distance: How the communications revolution will change our lives? Harvard Business School Press, Boston

Choo S, Mokhtarian PL, Salomon I (2005) Does telecommuting reduce vehicle-miles traveled? An aggregate time series analysis for the U.S. Transportation 32(1):37-64

Fox M (1995) Transport planning and the human activity approach. Journal of Transport Geography 3(2):105-116

Gareis K (2003) Home-based versus mobile telework: The interrelationships between different types of telework. In: Jackson P, Rapp B (ed) Organisation and work beyond 2000. Springer-Verlag, Berlin, pp 171-185

Glaeser EL, Kohlhase JE (2004) Cities, regions and the decline of transport costs. Papers in Regional Science 83(1):197-228

Graham S, Marvin S (2000) Urban planning and the technological future of cities. In: Wheeler JO, Aoyama Y, Warf B (ed) Cities in the telecommunication age. Routledge, New York, pp $71-96$

Greene WH (1997) Econometric Analysis, 3rd edition. Prentice Hall, Upper Saddle River, NJ

Handy SL, Mokhtarian PL (1995) Planning for telecommuting: Measurement and policy issues. Journal of the American Planning Association 61(1):99-111

Heckman JJ, MaCurdy TE (1985) A Simultaneous Equations Linear Probability Model. Canadian Journal of Economics 18(1):28-37

Hall AR, Rudebusch GD, Wilcox DW (1996) Judging instrument relevance in instrumental variables estimation. International Economic Review 37(2):283-298 
Janelle DG (1986) Metropolitan expansion and the communications- transportation trade-off. In: Hanson S (ed) The geography of urban transportation. The Guilford Press, New York, pp $357-385$

Jiang Y (2008) Two empirical essays in environmental and urban economics. Ph.D. Dissertation, University of Maryland

Knoke W (1996) Bold new world: The essential road map to the twenty-first century. Kodansha International, New York

Leamer EE, Storper M (2001) The economic geography of the internet age. Journal of International Business Studies 32(4):641-666

Mitchell WJ (2000) E-topia: "Urban life, Jim—but not as we know it”. MIT Press, Cambridge, MA

Mokhtarian PL (1998) A synthetic approach to estimating the impacts of telecommuting on travel. Urban Studies 35(2):215-41

Mokhtarian PL, Collantes GO, Gertz C (2004) Telecommuting, residential location, and commute-distance traveled: evidence from State of California employees. Environment and Planning A 36(10):1877 - 1897

Mokhtarian PL, Handy SL, Salomon I (1995) Methodological issues in the estimation of the travel, energy and air quality impacts of telecommuting. Transportation Research $A$ 29(4):283-302

Mokhtarian PL, Ho CI, Hung SW, Lam TB, Raney EA, Redmond LS et al (1997) Residential area-based offices project: Final report on the evaluation of impacts. No. Research Report UCD-ITS-RR-97-17). Institute of Transportation Studies, University of California, Davis

Naisbitt J (1984) Megatrends: Ten new directions transforming our lives. Warner, New York

Naisbitt R (1995) The global paradox. Avon Books, New York

Negroponte N (1995) Being digital. Vintage Books, New York

Nelson D, Niles J (2000) Observations on the causes of nonwork travel growth. Transportation Research Board Paper. No. 00-1232, $79^{\text {th }}$ Annual Meeting, January 9-13

Niles JS (1994) Beyond telecommuting: A new paradigm for the effect of telecommunications on travel. Prepared for the US Department of Energy, Offices of Energy Research and Scientific Computing, Washington, DC 20585, Report No. DOE/ER-0626), September 
Ory DT, Mokhtarian PL (2005) The impact of telecommuting on the commute time, distance, and speed of state of California workers. Extracted from http://repositories.cdlib.org/itsdavis/UCD-ITS-RR-05-23 on April 02, 2009

Ory DT, Mokhtarian PL (2006) Which came first, the telecommuting or the residential relocation? An empirical analysis of causality. Urban Geography 27(7):590-609

Pagan AR, Hall D (1983) Diagnostic tests as residual analysis. Econometric Reviews 2:159-218

Pascal A (1987) The vanishing city. Urban Studies 24:597-603

Salomon I (1986) Telecommunications and travel: A review. Transport Research A 20:223-238

Shea J (1997) Instrument relevance in multivariate linear models: A simple measure. The Review of Economics and Statistics 79:348-352

Sinai T, Waldfogel J (2004) Geography and the internet: Is the internet a substitute or a complement for cities? Journal of Urban Economics 56(1):1-24

Staiger D, Stock JH (1997) Instrumental variables regression with weak instruments. Econometrica 65(3):557-586

Stock JH (2010) The other transformation in econometric practice: robust tools for inference. Journal of Economic Perspectives 24(2):83-94

Storper M, Manville M (2006) Behaviour, preferences and cities: Urban theory and urban resurgence. Urban Studies 43(8):1247-1274

Strathman JG, Dueker KJ, Davis JS (1994) Effects of household structure and selected travel characteristics on trip chaining. Transportation 21:23-45

Toffler A (1981) The third wave. William Morrow, New York

Webber MM (1963) Order in diversity: Community without propinquity. In: Wingo L (ed) Cities and space: The future use of urban land. Johns Hopkins Press, Baltimore, MD, pp 25-54

Webber MM (1996) Tenacious cities. Proceedings of the NCGIA-Sponsored Research Conference on Spatial Technologies, Geographic Information, and the City, 214-218

Webber MM (1968) The post-city age. Daedalus 97(4):1091-1110

Zahavi Y (1979) The UMOT project. A report prepared for the U.S. Department of Transportation. Report No. DOT-RSPA-DPB-20-79-3

Zahavi Y, Ryan JM (1980a) Stability of travel components over time. Transportation Research Record 750:19-26 
Zahavi Y, Talvitie A (1980b) Regularities in travel time and money expenditures. Transportation Research Record 750:13-19 
Table 1 Workers' Commute Trips, Work Trips and Non-work Trips by Telecommuting Status (2001)

\begin{tabular}{|c|c|c|c|c|c|c|c|}
\hline \multirow[b]{2}{*}{ Trip Type } & \multicolumn{4}{|c|}{ Telecommuter } & \multicolumn{3}{|c|}{ Non-telecommuter } \\
\hline & Measure & Mean & Std. Dev. & Obs & Mean & Std. Dev. & Obs \\
\hline \multirow{2}{*}{ Commute Trip (one-way) } & Distance & 15.02 & 35.87 & 3208 & 12.25 & 18.14 & 66925 \\
\hline & Duration & 24.12 & 26.81 & 2959 & 21.54 & 18.89 & 65790 \\
\hline \multirow{3}{*}{ Total Work Trips (in trip day) } & Distance & 39.21 & 80.09 & 1687 & 29.22 & 88.71 & 43010 \\
\hline & Duration & 67.52 & 76.77 & 1687 & 53.22 & 58.04 & 43010 \\
\hline & Frequency & 2.71 & 1.49 & 1687 & 2.36 & 1.06 & 43010 \\
\hline \multirow{3}{*}{$\begin{array}{c}\text { Total Nonwork Trips (in trip } \\
\text { day) }\end{array}$} & Distance & 38.89 & 61.41 & 2658 & 33.20 & 65.44 & 50953 \\
\hline & Duration & 78.20 & 76.92 & 2658 & 66.60 & 70.75 & 50953 \\
\hline & Frequency & 4.39 & 2.85 & 2658 & 3.87 & 2.53 & 50953 \\
\hline \multirow{3}{*}{$\begin{array}{c}\text { Total Shopping Trips (in trip } \\
\text { day) }\end{array}$} & Distance & 18.04 & 36.19 & 1486 & 15.98 & 34.93 & 26288 \\
\hline & Duration & 36.72 & 47.06 & 1486 & 33.49 & 41.74 & 26288 \\
\hline & Frequency & 2.33 & 1.43 & 1486 & 2.25 & 1.41 & 26288 \\
\hline \multirow{3}{*}{$\begin{array}{l}\text { Total Other Family/Personal } \\
\text { Business Trips (in trip day) }\end{array}$} & Distance & 20.21 & 43.76 & 1395 & 16.35 & 46.70 & 25031 \\
\hline & Duration & 39.53 & 50.00 & 1395 & 33.36 & 41.71 & 25031 \\
\hline & Frequency & 2.57 & 1.71 & 1395 & 2.31 & 1.46 & 25031 \\
\hline \multirow{3}{*}{$\begin{array}{l}\text { Total School/Church Trips } \\
\text { (in trip day) }\end{array}$} & Distance & 15.11 & 23.16 & 265 & 14.20 & 21.74 & 6415 \\
\hline & Duration & 32.40 & 32.66 & 265 & 31.92 & 32.30 & 6415 \\
\hline & Frequency & 2.01 & 0.83 & 265 & 2.01 & 0.86 & 6415 \\
\hline \multirow{3}{*}{$\begin{array}{l}\text { Total Medical/Dentral Trips } \\
\text { (in trip day) }\end{array}$} & Distance & 20.24 & 35.72 & 185 & 16.20 & 26.73 & 2825 \\
\hline & Duration & 38.16 & 43.06 & 185 & 33.42 & 34.26 & 2825 \\
\hline & Frequency & 1.76 & 0.84 & 185 & 1.68 & 0.72 & 2825 \\
\hline \multirow{3}{*}{$\begin{array}{c}\text { Total Visit Friends/Relatives } \\
\text { Trips (in trip day) }\end{array}$} & Distance & 34.30 & 66.15 & 435 & 31.73 & 80.29 & 8978 \\
\hline & Duration & 53.03 & 74.33 & 435 & 48.40 & 67.87 & 8978 \\
\hline & Frequency & 1.87 & 0.86 & 435 & 1.87 & 0.90 & 8978 \\
\hline \multirow{3}{*}{$\begin{array}{c}\text { Total Other } \\
\text { Social/Recreational Trips (in } \\
\text { trip day) }\end{array}$} & Distance & 19.55 & 38.41 & 1315 & 20.06 & 43.86 & 21982 \\
\hline & Duration & 45.18 & 51.82 & 1315 & 42.96 & 54.79 & 21982 \\
\hline & Frequency & 2.24 & 1.27 & 1315 & 2.09 & 1.12 & 21982 \\
\hline
\end{tabular}

1. Workers who only work at home (e.g. home-based business) are excluded.

2. Commute trips are measured in terms of one-way commute distance and duration.

3. Total work trips are measured in total trip distance, duration and frequency for each person in his/her trip day.

4. Non-work trips are measured in total trip distance, duration and frequency by trip type for each person in his/her trip day.

5. Trip-day total work trips are the summation of all to/from work trips and work related business trips.

6. Trip-day total nonwork trips are the summation of personal total shopping trips, personal total other family/personal business trips, personal school/church trips, etc. 
Table 1 (continued) Workers' Commute Trips, Work Trips and Non-work Trips by Telecommuting Status (2009)

\begin{tabular}{|c|c|c|c|c|c|c|c|}
\hline \multirow[b]{2}{*}{ rip Type } & \multirow[b]{2}{*}{ Measure } & \multicolumn{3}{|c|}{ Telecommuter } & \multicolumn{3}{|c|}{ Non-telecommuter } \\
\hline & & Mean & Std. Dev. & Obs & Mean & Std. Dev. & Obs \\
\hline \multirow{2}{*}{ Commute Trip (one-way) } & Distance & 21.32 & 44.51 & 5321 & 13.73 & 20.90 & 113058 \\
\hline & Durat & 31.45 & 34.67 & 4995 & 23.40 & 20.17 & 110855 \\
\hline \multirow{3}{*}{$\begin{array}{c}\text { Total Work Trips (in trip } \\
\text { day) }\end{array}$} & Dista & 42.72 & 77.64 & 2468 & 29.80 & 67.79 & 69263 \\
\hline & Dura & 71.95 & 73.64 & 2468 & 54.29 & 53.75 & 69263 \\
\hline & Fre & 2.43 & 1.21 & 2468 & 2.31 & 1.04 & 69263 \\
\hline \multirow{3}{*}{$\begin{array}{c}\text { Total Nonwork Trips (in trip } \\
\text { day) }\end{array}$} & Dista & 36.14 & 66.11 & 4489 & 31.23 & 65.75 & 84775 \\
\hline & Dura & 73.63 & 73.42 & 4489 & 64.39 & 68.23 & 84775 \\
\hline & Frequ & 4.18 & 2.62 & 4489 & 3.77 & 2.42 & 84775 \\
\hline \multirow{3}{*}{$\begin{array}{l}\text { Total Shopping Trips (in trip } \\
\text { day) }\end{array}$} & Dista & 17.85 & 52.10 & 2214 & 15.40 & 31.79 & 41861 \\
\hline & Durat & 34.27 & 44.78 & 2214 & 32.88 & 41.41 & 41861 \\
\hline & Frequ & 2.23 & 1.36 & 2214 & 2.20 & 1.33 & 41861 \\
\hline \multirow{3}{*}{$\begin{array}{l}\text { Total Other Family/Personal } \\
\text { Business Trips (in trip day) }\end{array}$} & Dist & 18.96 & 40.55 & 2302 & 16.33 & 51.02 & 40087 \\
\hline & Duration & 38.92 & 43.61 & 2302 & 34.11 & 42.32 & 40087 \\
\hline & Frequ & 2.49 & 1.64 & 2302 & 2.28 & 1.45 & 40087 \\
\hline \multirow{3}{*}{$\begin{array}{l}\text { Total School/Church Trips } \\
\text { (in trip day) }\end{array}$} & Distar & 19.68 & 46.63 & 390 & 16.07 & 25.72 & 9626 \\
\hline & Durat & 35.47 & 47.31 & 390 & 33.67 & 31.49 & 9626 \\
\hline & Frequency & 2.06 & 1.00 & 390 & 2.04 & 0.80 & 9626 \\
\hline \multirow{3}{*}{$\begin{array}{l}\text { Total Medical/Dentral Trips } \\
\text { (in trip day) }\end{array}$} & Distance & 18.04 & 24.15 & 294 & 18.56 & 31.26 & 5338 \\
\hline & Duration & 35.86 & 32.19 & 294 & 36.92 & 44.32 & 5338 \\
\hline & Frequency & 1.75 & 0.67 & 294 & 1.69 & 0.76 & 5338 \\
\hline \multirow{3}{*}{$\begin{array}{c}\text { Total Visit Friends/Relatives } \\
\text { Trips (in trip day) }\end{array}$} & Distance & 34.76 & 70.87 & 571 & 30.71 & 76.20 & 12404 \\
\hline & Duration & 51.98 & 71.33 & 571 & 46.98 & 63.74 & 12404 \\
\hline & Frequency & 1.88 & 0.88 & 571 & 1.87 & 0.85 & 12404 \\
\hline \multirow{3}{*}{$\begin{array}{c}\text { Total Other } \\
\text { Social/Recreational Trips (in } \\
\text { trip day) }\end{array}$} & Distance & 19.15 & 37.18 & 2414 & 18.30 & 48.82 & 39009 \\
\hline & Duration & 45.99 & 52.77 & 2414 & 41.31 & 49.40 & 39009 \\
\hline & Frequency & 2.36 & 1.30 & 2414 & 2.17 & 1.15 & 39009 \\
\hline
\end{tabular}

1. Workers who only work at home (e.g. home-based business) are excluded.

2. Commute trips are measured in terms of one-way commute distance and duration.

3. Total work trips are measured in total trip distance, duration and frequency for each person in his/her trip day.

4. Non-work trips are measured in total trip distance, duration and frequency by trip type for each person in his/her trip day.

5. Trip-day total work trips are the summation of all to/from work trips and work related business trips.

6. Trip-day total nonwork trips are the summation of personal total shopping trips, personal total other family/personal business trips, personal school/church trips, etc. 
Table 2 Workers' Commute Trips and Non-work Trips by Place of Residence (2001)

\begin{tabular}{|c|c|c|c|c|c|c|c|c|c|c|}
\hline \multirow[b]{2}{*}{ Trip Type } & \multirow[b]{2}{*}{ Measure } & \multicolumn{3}{|c|}{ Urbanized } & \multicolumn{3}{|c|}{ Suburban } & \multicolumn{3}{|c|}{ Rural } \\
\hline & & Mean & Std. Dev. & Num. Obs. & Mean & Std. Dev. & Num. Obs. & Mean & Std. Dev. & Num. Obs. \\
\hline \multirow{2}{*}{$\begin{array}{l}\text { Commute Trip } \\
\text { (one-way) }\end{array}$} & Distance & 10.92 & 17.52 & 43430 & 15.76 & 20.04 & 14329 & 13.54 & 23.49 & 12374 \\
\hline & Duration & 21.42 & 18.59 & 42761 & 23.87 & 20.30 & 13973 & 19.93 & 20.36 & 12015 \\
\hline \multirow{3}{*}{$\begin{array}{l}\text { Total Nonwork } \\
\text { Trips (in trip day) }\end{array}$} & Distance & 30.72 & 65.22 & 33803 & 37.68 & 60.69 & 10632 & 38.81 & 69.78 & 9176 \\
\hline & Duration & 66.70 & 70.08 & 33803 & 67.75 & 70.78 & 10632 & 68.26 & 75.16 & 9176 \\
\hline & Frequency & 3.95 & 2.58 & 33803 & 3.76 & 2.47 & 10632 & 3.88 & 2.52 & 9176 \\
\hline \multirow{3}{*}{$\begin{array}{l}\text { Total Shopping } \\
\text { Trips (in trip day) }\end{array}$} & Distance & 14.22 & 35.09 & 17499 & 18.63 & 31.08 & 5436 & 20.00 & 38.19 & 4839 \\
\hline & Duration & 32.79 & 40.46 & 17499 & 34.23 & 39.77 & 5436 & 36.20 & 49.39 & 4839 \\
\hline & Frequency & 2.29 & 1.44 & 17499 & 2.18 & 1.37 & 5436 & 2.23 & 1.37 & 4839 \\
\hline \multirow{3}{*}{$\begin{array}{c}\text { Total Other } \\
\text { Family/Personal } \\
\text { Business Trips (in } \\
\text { trip day) } \\
\end{array}$} & Distance & 15.37 & 50.71 & 16706 & 18.04 & 35.40 & 5178 & 19.18 & 41.34 & 4542 \\
\hline & Duration & 33.56 & 42.21 & 16706 & 33.95 & 40.43 & 5178 & 33.85 & 44.15 & 4542 \\
\hline & Frequency & 2.34 & 1.49 & 16706 & 2.27 & 1.44 & 5178 & 2.34 & 1.49 & 4542 \\
\hline \multirow{3}{*}{$\begin{array}{c}\text { Total } \\
\text { School/Church } \\
\text { Trips (in trip day) }\end{array}$} & Distance & 12.47 & 19.44 & 4165 & 17.84 & 25.41 & 1297 & 16.41 & 24.46 & 1218 \\
\hline & Duration & 32.12 & 31.82 & 4165 & 32.79 & 34.96 & 1297 & 30.44 & 30.97 & 1218 \\
\hline & Frequency & 2.02 & 0.85 & 4165 & 1.97 & 0.88 & 1297 & 2.04 & 0.87 & 1218 \\
\hline \multirow{3}{*}{$\begin{array}{c}\text { Total } \\
\text { Medical/Dentral } \\
\text { Trips (in trip day) } \\
\end{array}$} & Distance & 13.26 & 23.98 & 1931 & 20.69 & 27.58 & 611 & 24.05 & 36.57 & 468 \\
\hline & Duration & 31.99 & 33.96 & 1931 & 36.15 & 32.34 & 611 & 37.63 & 40.85 & 468 \\
\hline & Frequency & 1.69 & 0.76 & 1931 & 1.67 & 0.66 & 611 & 1.65 & 0.68 & 468 \\
\hline \multirow{3}{*}{$\begin{array}{c}\text { Total Visit } \\
\text { Friends/Relatives } \\
\text { Trips (in trip day) }\end{array}$} & Distance & 30.99 & 76.09 & 5704 & 33.89 & 75.95 & 1970 & 32.33 & 94.10 & 1739 \\
\hline & Duration & 49.22 & 70.26 & 5704 & 48.56 & 65.38 & 1970 & 46.67 & 64.27 & 1739 \\
\hline & Frequency & 1.87 & 0.89 & 5704 & 1.86 & 0.93 & 1970 & 1.88 & 0.88 & 1739 \\
\hline \multirow{3}{*}{$\begin{array}{c}\text { Total Other } \\
\text { Social/Recreationa } \\
\text { I Trips (in trip day) }\end{array}$} & Distance & 18.49 & 42.92 & 15063 & 23.13 & 44.92 & 4469 & 22.51 & 44.25 & 3765 \\
\hline & Duration & 42.76 & 53.44 & 15063 & 44.34 & 57.44 & 4469 & 42.93 & 55.91 & 3765 \\
\hline & Frequency & 2.13 & 1.15 & 15063 & 2.04 & 1.07 & 4469 & 2.05 & 1.10 & 3765 \\
\hline
\end{tabular}

1. Workers who only work at home (e.g. home-based business) are excluded.

2. Commute trips are measured in terms of one-way commute distance and duration.

3. Non-work trips are measured in total trip distance, duration and frequency by trip type for each person in his/her trip day.

4. Trip-day total nonwork trips are the summation of personal total shopping trips, personal total other family/personal business trips, personal school/church trips, etc.

5. Trip-day total work trips are not included, since their patterns are similar to commute trips. This is not surprising because commute trips are the major parts of daily total work trips for most workers.

6. Urbanized area is defined as having at least 50,000 population, may or may not be in MSA.

7. Suburban area is defined as within MSA but not in urbanized area.

8. Rural area is defined as neither in urbanized area nor in MSA. 
Table 2 (continued) Workers' Commute Trips and Non-work Trips by Place of Residence (2009)

\begin{tabular}{|c|c|c|c|c|c|c|c|c|c|c|}
\hline \multirow[b]{2}{*}{ Trip Type } & \multirow[b]{2}{*}{ Measure } & \multicolumn{3}{|c|}{ Urbanized } & \multicolumn{3}{|c|}{ Suburban } & \multicolumn{3}{|c|}{ Rural } \\
\hline & & Mean & Std. Dev. & Num. Obs. & Mean & Std. Dev. & Num. Obs. & Mean & Std. Dev. & Num. Obs. \\
\hline \multirow{2}{*}{$\begin{array}{l}\text { Commute Trip } \\
\text { (one-way) }\end{array}$} & Distance & 12.49 & 20.84 & 72465 & 17.68 & 23.46 & 25160 & 15.24 & 26.30 & 20753 \\
\hline & Duration & 23.18 & 19.64 & 71171 & 26.95 & 22.82 & 24498 & 21.85 & 23.19 & 20180 \\
\hline \multirow{3}{*}{$\begin{array}{l}\text { Total Nonwork } \\
\text { Trips (in trip day) }\end{array}$} & Distance & 28.58 & 66.20 & 55861 & 35.82 & 68.64 & 18298 & 36.95 & 59.74 & 15105 \\
\hline & Duration & 63.76 & 66.41 & 55861 & 66.74 & 70.32 & 18298 & 66.63 & 73.74 & 15105 \\
\hline & Frequency & 3.87 & 2.48 & 55861 & 3.65 & 2.34 & 18298 & 3.71 & 2.38 & 15105 \\
\hline \multirow{3}{*}{$\begin{array}{l}\text { Total Shopping } \\
\text { Trips (in trip day) }\end{array}$} & Distance & 13.25 & 30.99 & 27573 & 18.62 & 35.29 & 8931 & 20.18 & 36.91 & 7571 \\
\hline & Duration & 31.44 & 38.90 & 27573 & 35.13 & 44.37 & 8931 & 35.87 & 47.05 & 7571 \\
\hline & Frequency & 2.23 & 1.35 & 27573 & 2.15 & 1.30 & 8931 & 2.19 & 1.32 & 7571 \\
\hline \multirow{3}{*}{$\begin{array}{c}\text { Total Other } \\
\text { Family/Personal } \\
\text { Business Trips (in } \\
\text { trip day) }\end{array}$} & Distance & 15.12 & 50.71 & 26776 & 18.98 & 56.64 & 8536 & 18.56 & 40.83 & 7077 \\
\hline & Duration & 34.19 & 41.76 & 26776 & 35.27 & 41.87 & 8536 & 33.97 & 45.39 & 7077 \\
\hline & Frequency & 2.32 & 1.49 & 26776 & 2.22 & 1.43 & 8536 & 2.25 & 1.43 & 7077 \\
\hline \multirow{3}{*}{$\begin{array}{c}\text { Total } \\
\text { School/Church } \\
\text { Trips (in trip day) }\end{array}$} & Distance & 14.42 & 26.74 & 6114 & 19.40 & 25.45 & 2040 & 18.62 & 28.14 & 1862 \\
\hline & Duration & 33.43 & 31.55 & 6114 & 35.56 & 31.10 & 2040 & 32.77 & 35.56 & 1862 \\
\hline & Frequency & 2.03 & 0.79 & 6114 & 2.02 & 0.79 & 2040 & 2.10 & 0.86 & 1862 \\
\hline \multirow{3}{*}{$\begin{array}{c}\text { Total } \\
\text { Medical/Dentral } \\
\text { Trips (in trip day) }\end{array}$} & Distance & 14.42 & 23.92 & 3532 & 21.79 & 31.91 & 1110 & 29.56 & 45.45 & 990 \\
\hline & Duration & 33.48 & 37.95 & 3532 & 39.88 & 50.98 & 1110 & 45.59 & 52.18 & 990 \\
\hline & Frequency & 1.70 & 0.74 & 3532 & 1.67 & 0.78 & 1110 & 1.69 & 0.78 & 990 \\
\hline \multirow{3}{*}{$\begin{array}{c}\text { Total Visit } \\
\text { Friends/Relatives } \\
\text { Trips (in trip day) }\end{array}$} & Distance & 30.31 & 82.28 & 7781 & 32.48 & 67.83 & 2712 & 30.94 & 62.61 & 2482 \\
\hline & Duration & 46.72 & 62.04 & 7781 & 48.81 & 66.72 & 2712 & 46.95 & 67.43 & 2482 \\
\hline & Frequency & 1.86 & 0.84 & 7781 & 1.87 & 0.89 & 2712 & 1.89 & 0.85 & 2482 \\
\hline \multirow{3}{*}{$\begin{array}{c}\text { Total Other } \\
\text { Social/Recreationa } \\
\text { I Trips (in trip day) }\end{array}$} & Distance & 16.88 & 48.87 & 26747 & 21.16 & 51.88 & 8279 & 20.83 & 39.51 & 6397 \\
\hline & Duration & 40.88 & 48.05 & 26747 & 43.15 & 51.54 & 8279 & 42.49 & 53.31 & 6397 \\
\hline & Frequency & 2.22 & 1.19 & 26747 & 2.11 & 1.13 & 8279 & 2.07 & 1.09 & 6397 \\
\hline
\end{tabular}

1. Workers who only work at home (e.g. home-based business) are excluded.

2. Commute trips are measured in terms of one-way commute distance and duration.

3. Non-work trips are measured in total trip distance, duration and frequency by trip type for each person in his/her trip day.

4. Trip-day total nonwork trips are the summation of personal total shopping trips, personal total other

family/personal business trips, personal school/church trips, etc.

5. Trip-day total work trips are not included, since their patterns are similar to commute trips. This is not surprising because commute trips are the major parts of daily total work trips for most workers.

6. Urbanized area is defined as having at least 50,000 population, may or may not be in MSA.

7. Suburban area is defined as within MSA but not in urbanized area.

8. Rural area is defined as neither in urbanized area nor in MSA. 
Table 3 Summary Statistics for Explanatory Variables

\begin{tabular}{lcccc}
\hline \multirow{2}{*}{ Variable } & \multicolumn{2}{c}{2001} & \multicolumn{2}{c}{2009} \\
\cline { 2 - 5 } Telecommuter (dummy) & Mean & Std. Dev. & Mean & Std. Dev. \\
Age & 0.046 & 0.2092 & 0.046 & 0.2090 \\
Male & 39.215 & 22.8348 & 47.211 & 23.9358 \\
Medical Condition & 0.476 & 0.4994 & 0.466 & 0.4988 \\
Less Than High School & 0.085 & 0.2789 & 0.124 & 0.3292 \\
High School Graduate or Some College & 0.122 & 0.3269 & 0.078 & 0.2678 \\
BA Degree & 0.523 & 0.4995 & 0.559 & 0.4965 \\
Graduate Degree & 0.249 & 0.4322 & 0.210 & 0.4071 \\
Sales or Service & 0.107 & 0.3086 & 0.153 & 0.3604 \\
Clerical or Administrative Support & 0.268 & 0.4430 & - & - \\
Manufacturing, Construction, Maintenance, or Farming & 0.124 & 0.3301 & - & - \\
Professional, Managerial or Technical & 0.197 & 0.3974 & - & - \\
Other Occupation & 0.406 & 0.4911 & - & - \\
Household Income (log) & 0.004 & 0.0669 & - & - \\
Child & 10.705 & 0.7677 & 10.841 & 0.8129 \\
Num. of Vehicles per Driver & 0.474 & 0.4993 & 0.368 & 0.4823 \\
Residence in Urbanized Area & 1.084 & 0.5142 & 1.120 & 0.5168 \\
Residence in Suburban Area & 0.302 & 0.4590 & 0.610 & 0.4878 \\
Residence in Rural Area & 0.518 & 0.4997 & 0.209 & 0.4068 \\
Not in a MSA & 0.180 & 0.3844 & 0.181 & 0.3852 \\
In an MSA less than 250,000 & 0.197 & 0.3981 & 0.198 & 0.3983 \\
In an MSA of 250,000 - 499,999 & 0.172 & 0.3775 & 0.112 & 0.3152 \\
In an MSA of 500,000 - 999,999 & 0.169 & 0.3748 & 0.083 & 0.2764 \\
In an MSA or CMSA of 1- 2 millions & 0.096 & 0.2952 & 0.107 & 0.3096 \\
In an MSA or CMSA of 3 million or more & 0.120 & 0.3247 & 0.217 & 0.4120 \\
\hline
\end{tabular}

1. Telecommuter is a dummy variable indicating whether the worker is telecommuting frequently (see definitions in the paper).

2. Medical Condition is a dummy variable indicating whether this person has a temporary or permanent condition or handicap that makes it difficult to travel outside of the home.

3. For education dummy variables, "less than high school" will be used as the reference in regressions;

4. For occupation dummy variables, "Manufacturing, Cons., Maintenance, or Farming" will be the reference;

5. For place of residence dummy variables, "residence in suburban area" will be the reference;

6. For MSA size dummy variables, "in an MSA of less than 250,000" will be the reference;

7. The sample includes all workers, not just those who commute by personal vehicles. 
Table 4 Workers' One-way Commute Distance and Duration

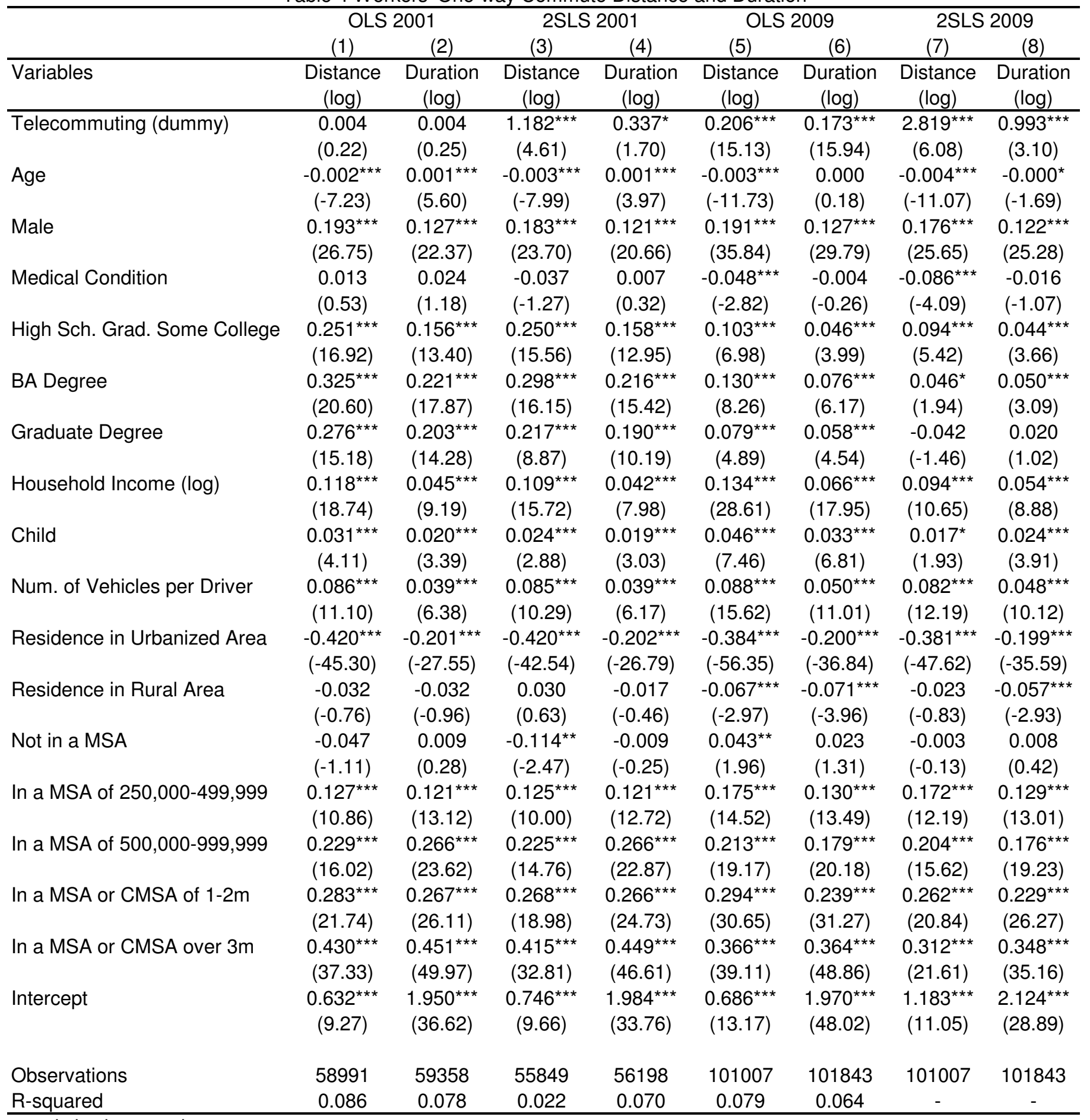

t-statistics in parentheses

*** $p<0.01,{ }^{* *} p<0.05,{ }^{*} p<0.1$

1. For 2001 models that include occupation variables, see Appendix 2;

2. For education dummy variables, the reference is "less than high school";

3. For place of residence dummy variables, the reference is "residence in suburban area";

4. For MSA size dummy variables, the reference is "in an MSA of less than 250,000";

5. In order to eliminate the endogeneity problem associated with transportation mode, sample is restricted to workers who use personal vehicles for commuting. Workers commuting by public transit or other modes are dropped. 
Table 5 Worker's Daily Total Work Trips

\begin{tabular}{|c|c|c|c|c|c|c|}
\hline \multirow[b]{3}{*}{ Variables } & \multicolumn{3}{|c|}{ Daily Total Work Trip 2001 (OLS) } & \multicolumn{3}{|c|}{ Daily Total Work Trip 2009 (OLS) } \\
\hline & $(1)$ & $(2)$ & $(3)$ & $(4)$ & $(5)$ & (6) \\
\hline & \multicolumn{6}{|c|}{ Distance $(\log )$ Duration $(\log )$ Frequency $(\log )$ Distance $(\log )$ Duration(log)Frequency $(\log )$} \\
\hline \multirow[t]{2}{*}{ Telecommuter (dummy) } & $0.108^{\star \star *}$ & $0.104^{\star \star \star}$ & $0.066^{\star * \star}$ & $0.208^{* * *}$ & $0.171^{* * *}$ & $0.016^{\star \star \star}$ \\
\hline & $(4.14)$ & $(5.32)$ & $(10.10)$ & $(10.36)$ & $(11.23)$ & (3.10) \\
\hline \multirow[t]{2}{*}{ Age } & $-0.002^{* \star *}$ & $0.002^{* \star *}$ & $0.001^{* * *}$ & $-0.001^{* * *}$ & $0.001^{* * *}$ & $0.001^{* * *}$ \\
\hline & $(-4.06)$ & $(6.36)$ & (8.07) & $(-4.03)$ & $(5.68)$ & $(13.70)$ \\
\hline \multirow[t]{2}{*}{ Male } & $0.301^{* * *}$ & $0.215^{\star \star \star}$ & $0.034^{\star * *}$ & $0.294^{* * \star}$ & $0.209^{* * *}$ & $0.031^{* * *}$ \\
\hline & $(30.44)$ & $(28.88)$ & $(13.54)$ & (39.98) & $(37.46)$ & (16.52) \\
\hline \multirow[t]{2}{*}{ Medical Condition } & $-0.072^{*}$ & -0.016 & $-0.023^{\star *}$ & $-0.083^{\star \star *}$ & $-0.033^{*}$ & $-0.022^{\star \star \star}$ \\
\hline & $(-1.92)$ & $(-0.57)$ & $(-2.43)$ & $(-3.30)$ & $(-1.71)$ & $(-3.47)$ \\
\hline \multirow[t]{2}{*}{ High Sch. Grad. Some Col. } & $0.241^{\star \star *}$ & $0.103^{\star * *}$ & $0.022^{* \star *}$ & $0.171^{* * *}$ & -0.011 & 0.006 \\
\hline & $(11.44)$ & $(6.50)$ & $(4.16)$ & $(8.42)$ & $(-0.70)$ & $(1.20)$ \\
\hline \multirow[t]{2}{*}{ BA Degree } & $0.319^{* * *}$ & $0.159^{* * *}$ & $0.042^{* \star *}$ & $0.210^{* * *}$ & 0.020 & $0.022^{* * *}$ \\
\hline & $(14.27)$ & $(9.48)$ & $(7.45)$ & $(9.78)$ & $(1.22)$ & $(4.04)$ \\
\hline \multirow[t]{2}{*}{ Graduate Degree } & $0.235^{\star \star \star}$ & $0.124^{\star \star \star}$ & $0.052^{\star \star \star}$ & $0.125^{\star \star \star}$ & -0.018 & $0.028^{\star \star \star}$ \\
\hline & $(9.24)$ & $(6.49)$ & (8.07) & (5.63) & $(-1.04)$ & $(4.91)$ \\
\hline \multirow[t]{2}{*}{ Household Income (log) } & $0.162^{\star \star *}$ & $0.040^{* * *}$ & $0.007^{* * *}$ & $0.156^{\star \star \star}$ & $0.050^{* * *}$ & $0.008^{* * *}$ \\
\hline & $(18.60)$ & $(6.09)$ & (3.29) & $(24.24)$ & $(10.30)$ & $(5.15)$ \\
\hline \multirow[t]{2}{*}{ Child } & 0.003 & -0.007 & $0.006^{\star \star}$ & 0.011 & -0.001 & 0.000 \\
\hline & $(0.32)$ & $(-0.96)$ & $(2.45)$ & $(1.35)$ & $(-0.13)$ & $(0.20)$ \\
\hline \multirow[t]{2}{*}{ Num. of Vehicles per Driver } & $0.125^{\star \star *}$ & $0.045^{\star \star \star}$ & $0.010^{* * *}$ & $0.105^{\star * \star}$ & $0.051^{* * *}$ & $0.012^{\star \star *}$ \\
\hline & $(11.91)$ & $(5.71)$ & (3.94) & $(13.38)$ & (8.59) & $(6.22)$ \\
\hline \multirow[t]{2}{*}{ Residence in Urbanized Area } & $-0.386^{\star * *}$ & $-0.146^{\star \star *}$ & $0.006^{\star \star}$ & $-0.376^{\star \star \star}$ & $-0.156^{\star \star *}$ & $0.011^{\star * *}$ \\
\hline & $(-30.39)$ & $(-15.30)$ & $(1.99)$ & $(-40.01)$ & $(-21.88)$ & $(4.39)$ \\
\hline \multirow[t]{2}{*}{ Residence in Rural Area } & -0.091 & -0.058 & -0.001 & -0.020 & $-0.051^{* *}$ & 0.003 \\
\hline & $(-1.54)$ & $(-1.31)$ & $(-0.07)$ & $(-0.65)$ & $(-2.15)$ & $(0.36)$ \\
\hline \multirow[t]{2}{*}{ Not in a MSA } & 0.038 & 0.069 & 0.012 & -0.004 & 0.012 & 0.008 \\
\hline & $(0.65)$ & $(1.59)$ & $(0.84)$ & $(-0.14)$ & $(0.52)$ & $(1.09)$ \\
\hline \multirow[t]{2}{*}{ In a MSA of $250,000-499,99 \mathrm{c}$} & $0.101^{* * *}$ & $0.105^{\star \star *}$ & $-0.008^{*}$ & $0.149^{\star \star *}$ & $0.100^{* * *}$ & $-0.011^{* \star *}$ \\
\hline & $(6.21)$ & (8.53) & $(-1.89)$ & $(8.96)$ & $(7.98)$ & $(-2.68)$ \\
\hline \multirow[t]{2}{*}{ In a MSA of $500,000-999,99 \mathrm{c}$} & $0.177^{* \star *}$ & $0.242^{\star \star \star}$ & $-0.020^{\star \star \star}$ & $0.185^{\star \star \star}$ & $0.135^{\star \star *}$ & $-0.022^{\star \star \star}$ \\
\hline & (8.98) & $(16.26)$ & $(-3.95)$ & $(12.13)$ & $(11.69)$ & $(-5.70)$ \\
\hline \multirow[t]{2}{*}{ In a MSA or CMSA of $1-2 m$} & $0.256^{\star * *}$ & $0.236^{\star \star *}$ & $-0.018^{* * *}$ & $0.245^{\star \star *}$ & $0.190^{* * *}$ & $-0.022^{* * *}$ \\
\hline & $(14.30)$ & $(17.50)$ & $(-3.94)$ & $(18.60)$ & $(19.00)$ & $(-6.51)$ \\
\hline \multirow[t]{2}{*}{ In a MSA or CMSA over $3 \mathrm{~m}$} & $0.363^{* * *}$ & $0.434^{\star \star \star}$ & $-0.024^{\star \star \star}$ & $0.311^{\star * *}$ & $0.320^{* * *}$ & $-0.031^{* * *}$ \\
\hline & (23.19) & $(36.80)$ & $(-6.18)$ & $(24.23)$ & (32.85) & $(-9.37)$ \\
\hline \multirow[t]{2}{*}{ Weekend } & $-0.163^{* * *}$ & $-0.163^{\star * *}$ & $-0.068^{\star * *}$ & $-0.178^{\star \star \star}$ & $-0.197^{\star * *}$ & $-0.069^{\star \star \star}$ \\
\hline & $(-9.73)$ & $(-12.92)$ & $(-16.17)$ & $(-13.82)$ & $(-20.16)$ & $(-21.05)$ \\
\hline \multirow[t]{2}{*}{ Intercept } & $0.736^{\star * *}$ & $2.806^{\star * *}$ & $1.019^{* * *}$ & $0.921^{* * *}$ & $2.915^{\star * *}$ & $0.992^{\star \star *}$ \\
\hline & (7.84) & $(39.71)$ & (43.29) & $(12.92)$ & (53.92) & $(54.57)$ \\
\hline Observations & 39392 & 39392 & 39392 & 64755 & 64755 & 64755 \\
\hline R-squared & 0.086 & 0.078 & 0.024 & 0.082 & 0.065 & 0.023 \\
\hline
\end{tabular}

t-statistics in parentheses

${ }^{* * *} p<0.01,{ }^{* *} p<0.05,{ }^{*} p<0.1$

1. To eliminate the endogeneity problem associated with transportation mode, the sample is restricted to workers who used personal vehicles in these work trips. 
Table 6 Worker's Daily Non-work Trips

\begin{tabular}{|c|c|c|c|c|c|c|c|c|c|}
\hline \multirow[b]{2}{*}{ Trip Type } & \multirow[b]{2}{*}{$\begin{array}{l}\text { Dep. Var. } \\
\text { (in log) }\end{array}$} & \multicolumn{4}{|c|}{ (1) OLS 2001} & \multicolumn{4}{|c|}{ (2) OLS 2009} \\
\hline & & $\begin{array}{l}\text { Telecommuter } \\
\text { (dummy) }\end{array}$ & t-value & $\begin{array}{l}\text { number } \\
\text { of obs }\end{array}$ & R-sq & $\begin{array}{c}\text { Telecommuter } \\
\text { (dummy) }\end{array}$ & t-value & $\begin{array}{l}\text { number } \\
\text { of obs }\end{array}$ & R-sq \\
\hline \multirow{3}{*}{$\begin{array}{c}\text { Total Nonwork } \\
\text { Trips }\end{array}$} & Distance & $0.161^{\star \star \star}$ & (6.52) & 47174 & 0.051 & $0.160^{\star \star \star}$ & (8.68) & 77846 & 0.049 \\
\hline & Duration & $0.160^{* * *}$ & (7.76) & 47174 & 0.043 & $0.142^{* * *}$ & (9.07) & 77846 & 0.033 \\
\hline & Frequency & $0.085^{\star * *}$ & (8.24) & 47174 & 0.043 & $0.074^{* * *}$ & (9.43) & 77846 & 0.046 \\
\hline \multirow{3}{*}{$\begin{array}{c}\text { Total Shopping } \\
\text { Trips }\end{array}$} & Distance & 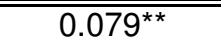 & $\overline{~(2.56)}$ & 24871 & 0.030 & $0.073^{\star \star \star}$ & $\overline{~(3.04)}$ & 40072 & 0.035 \\
\hline & Duration & $0.076^{\star \star \star}$ & (2.91) & 24871 & 0.024 & $0.046^{\star *}$ & (2.22) & 40072 & 0.022 \\
\hline & Frequency & $0.032^{* * *}$ & (3.10) & 24871 & 0.029 & $0.018^{* *}$ & (2.22) & 40072 & 0.037 \\
\hline Total Other & Distance & $0.158^{\star \star *}$ & $(4.88)$ & 23250 & 0.017 & $0.141^{\star \star \star}$ & (5.67) & 36606 & 0.020 \\
\hline \multirow{2}{*}{$\begin{array}{c}\text { Family/Personal } \\
\text { Business Trips }\end{array}$} & Duration & $0.128^{* * *}$ & (4.75) & 23250 & 0.014 & $0.133^{\star * *}$ & (6.35) & 36606 & 0.009 \\
\hline & Frequency & $0.063^{* * *}$ & (5.53) & 23250 & 0.025 & $0.050^{\star * \star}$ & (5.67) & 36606 & 0.022 \\
\hline \multirow{3}{*}{$\begin{array}{c}\text { Total } \\
\text { School/Church } \\
\text { Trips }\end{array}$} & Distance & 0.022 & $(0.33)$ & 5758 & 0.045 & 0.083 & (1.60) & 8347 & 0.048 \\
\hline & Duration & 0.076 & (1.49) & 5758 & 0.032 & 0.031 & (0.79) & 8347 & 0.031 \\
\hline & Frequency & 0.015 & $(0.87)$ & 5758 & 0.037 & 0.012 & (0.93) & 8347 & 0.033 \\
\hline \multirow{3}{*}{$\begin{array}{c}\text { Total } \\
\text { Medical/Dentral } \\
\text { Trips } \\
\end{array}$} & Distance & 0.119 & (1.43) & 2682 & 0.037 & 0.041 & (0.65) & 5129 & 0.048 \\
\hline & Duration & 0.067 & (1.02) & 2682 & 0.027 & 0.011 & $(0.21)$ & 5129 & 0.039 \\
\hline & Frequency & 0.029 & (1.42) & 2682 & 0.016 & $0.034^{* *}$ & (2.08) & 5129 & 0.013 \\
\hline \multirow{3}{*}{$\begin{array}{c}\text { Total Visit } \\
\text { Friends/Relatives } \\
\text { Trips }\end{array}$} & Distance & 0.081 & (1.23) & 8310 & 0.039 & 0.065 & (1.14) & 11219 & 0.029 \\
\hline & Duration & 0.059 & (1.15) & 8310 & 0.035 & 0.039 & $(0.87)$ & 11219 & 0.021 \\
\hline & Frequency & 0.008 & $(0.56)$ & 8310 & 0.021 & 0.007 & (0.55) & 11219 & 0.019 \\
\hline \multirow{3}{*}{$\begin{array}{c}\text { Total Other } \\
\text { Social/Recreational } \\
\text { Trips }\end{array}$} & Distance & -0.002 & $(-0.06)$ & 18791 & 0.048 & $0.098^{\star \star \star}$ & (3.75) & 32425 & 0.041 \\
\hline & Duration & 0.033 & $(1.09)$ & 18791 & 0.037 & $0.097^{\star \star *}$ & (4.46) & 32425 & 0.027 \\
\hline & Frequency & $0.031^{* * *}$ & (2.93) & 18791 & 0.033 & $0.045^{\star \star *}$ & (5.75) & 32425 & 0.031 \\
\hline
\end{tabular}

t-statistics in parentheses

${ }^{* * *} p<0.01,{ }^{* *} p<0.05,{ }^{*} p<0.1$

1. For all models, control variables include age, male, medical condition, edu, household income (log), child, number of vehicles per driver, residence in urbanized area, residence in rural area, not in a MSA, in a MSA of 250000-499999, in a MSA of 500000-999999, in a MSA or CMSA of 1-2 millions,

In a MSA or CMSA over 3 millions or more, weekend

2. Coefficient estimates for all control variables are not shown.

3. The telecommuting dummy varible used in model (1) and (2) is whether the worker is a telecommuter.

4. To eliminate the endogeneity problem associated with transportation mode, the sample is restricted to workers who used personal vehicles in these non-work trips. 
Appendix 1 Spatial and Temporal Comparison of the Mean Differences of Workers' Trips

\begin{tabular}{|c|c|c|c|c|c|c|c|}
\hline \multirow{2}{*}{ Trip Type } & \multirow[b]{2}{*}{ Measure } & \multicolumn{3}{|c|}{ Urbanites2001 vs. Suburbanites2001 } & \multicolumn{3}{|c|}{ Urbanites2009 vs. Suburbanites2009 } \\
\hline & & $\overline{\text { Mean Urban }}$ & n Mean Suburban & t test & Mean Urban & Mean Suburban & $\mathrm{t}$ test \\
\hline \multirow{2}{*}{$\begin{array}{l}\text { Commute Trip } \\
\text { (one-way) }\end{array}$} & Distance & 10.92 & 15.76 & $27.62^{*}$ & 12.49 & 17.68 & $32.93^{*}$ \\
\hline & Duration & 21.42 & 23.87 & $13.23^{*}$ & 23.18 & 26.95 & $24.81^{*}$ \\
\hline \multirow{3}{*}{$\begin{array}{l}\text { Total Nonwork } \\
\text { Trips (in trip day) }\end{array}$} & Distance & 30.72 & 37.68 & $9.75^{*}$ & 28.58 & 35.82 & $12.71^{*}$ \\
\hline & Duration & 66.70 & 67.75 & 1.33 & 63.76 & 66.74 & $5.18^{*}$ \\
\hline & Frequency & 3.95 & 3.76 & $-6.88^{*}$ & 3.87 & 3.65 & $-10.57^{*}$ \\
\hline \multirow{3}{*}{$\begin{array}{l}\text { Total Shopping } \\
\text { Trips (in trip day) }\end{array}$} & Distance & 14.22 & 18.63 & $8.32^{*}$ & 13.25 & 18.62 & $13.74^{*}$ \\
\hline & Duration & 32.79 & 34.23 & $2.30^{*}$ & 31.44 & 35.13 & $7.51^{*}$ \\
\hline & Frequency & 2.29 & 2.18 & $-4.78^{*}$ & 2.23 & 2.15 & $-4.88^{*}$ \\
\hline \multirow{3}{*}{$\begin{array}{c}\text { Total Other } \\
\text { Family/Personal } \\
\text { Business Trips (in } \\
\text { trip day) } \\
\end{array}$} & Distance & 15.37 & 18.04 & $3.52^{*}$ & 15.12 & 18.98 & $5.96^{*}$ \\
\hline & Duration & 33.56 & 33.95 & 0.59 & 34.19 & 35.27 & $2.08^{*}$ \\
\hline & Frequency & 2.34 & 2.27 & $-3.10^{*}$ & 2.32 & 2.22 & $-5.43^{*}$ \\
\hline \multirow{3}{*}{$\begin{array}{c}\text { Total } \\
\text { School/Church } \\
\text { Trips (in trip day) } \\
\end{array}$} & Distance & 12.47 & 17.84 & $8.03^{*}$ & 14.42 & 19.40 & $7.38^{*}$ \\
\hline & Duration & 32.12 & 32.79 & 0.65 & 33.43 & 35.56 & $2.65^{*}$ \\
\hline & Frequency & 2.02 & 1.97 & -1.94 & 2.03 & 2.02 & -0.45 \\
\hline \multirow{3}{*}{$\begin{array}{c}\text { Total } \\
\text { Medical/Dentral } \\
\text { Trips (in trip day) }\end{array}$} & Distance & 13.26 & 20.69 & $6.43^{*}$ & 14.42 & 21.79 & $8.22^{*}$ \\
\hline & Duration & 31.99 & 36.15 & $2.67^{*}$ & 33.48 & 39.88 & $4.49^{*}$ \\
\hline & Frequency & 1.69 & 1.67 & -0.8 & 1.70 & 1.67 & -1.09 \\
\hline \multirow{3}{*}{$\begin{array}{c}\text { Total Visit } \\
\text { Friends/Relatives } \\
\text { Trips (in trip day) }\end{array}$} & Distance & 30.99 & 33.89 & 1.46 & 30.31 & 32.48 & 1.24 \\
\hline & Duration & 49.22 & 48.56 & -0.37 & 46.72 & 48.81 & 1.48 \\
\hline & Frequency & 1.87 & 1.86 & -0.32 & 1.86 & 1.87 & 0.67 \\
\hline \multirow{3}{*}{$\begin{array}{c}\text { Total Other } \\
\text { Social/Recreational } \\
\text { Trips (in trip day) }\end{array}$} & Distance & 18.49 & 23.13 & $6.28^{*}$ & 16.88 & 21.16 & $6.86^{*}$ \\
\hline & Duration & 42.76 & 44.34 & 1.7 & 40.88 & 43.15 & $3.70^{*}$ \\
\hline & Frequency & 2.13 & 2.04 & $-4.92^{*}$ & 2.22 & 2.11 & $-7.44^{*}$ \\
\hline
\end{tabular}


Appendix 1 (continued) Spatial and Temporal Comparison of the Mean Differences of Workers' Trips

\begin{tabular}{|c|c|c|c|c|c|c|c|}
\hline \multirow[b]{2}{*}{ Trip Type } & \multirow[b]{2}{*}{ Measure } & \multicolumn{3}{|c|}{ Urbanites2001 vs. Urbanites 2009} & \multicolumn{3}{|c|}{ Suburbanites2001 vs. Suburbanites 2009} \\
\hline & & Mean2001 & Mean2009 & $\mathrm{t}$ test & Mean2001 & Mean2009 & $\mathrm{t}$ test \\
\hline \multirow{2}{*}{$\begin{array}{c}\text { Commute Trip } \\
\text { (one-way) }\end{array}$} & Distance & 10.92 & 12.49 & $13.10^{*}$ & 15.76 & 17.68 & $8.22^{*}$ \\
\hline & Duration & 21.42 & 23.18 & $15.00^{*}$ & 23.87 & 26.95 & $13.25^{*}$ \\
\hline \multirow{3}{*}{$\begin{array}{l}\text { Total Nonwork } \\
\text { Trips (in trip day) }\end{array}$} & Distance & 30.72 & 28.58 & $-4.71^{*}$ & 37.68 & 35.82 & $-2.32^{*}$ \\
\hline & Duration & 66.70 & 63.76 & $-6.29^{*}$ & 67.75 & 66.74 & -1.17 \\
\hline & Frequency & 3.95 & 3.87 & $-4.90^{*}$ & 3.76 & 3.65 & $-3.77^{*}$ \\
\hline \multirow{3}{*}{$\begin{array}{l}\text { Total Shopping } \\
\text { Trips (in trip day) }\end{array}$} & Distance & 14.22 & 13.25 & $-3.07^{*}$ & 18.63 & 18.62 & -0.03 \\
\hline & Duration & 32.79 & 31.44 & $-3.53^{*}$ & 34.23 & 35.13 & 1.22 \\
\hline & Frequency & 2.29 & 2.23 & $-4.31^{*}$ & 2.18 & 2.15 & -1.37 \\
\hline \multirow{3}{*}{$\begin{array}{c}\text { Total Other } \\
\text { Family/Personal } \\
\text { Business Trips (in } \\
\text { trip day) } \\
\end{array}$} & Distance & 15.37 & 15.12 & -0.5 & 18.04 & 18.98 & 1.08 \\
\hline & Duration & 33.56 & 34.19 & 1.53 & 33.95 & 35.27 & 1.81 \\
\hline & Frequency & 2.34 & 2.32 & -1.19 & 2.27 & 2.22 & -1.74 \\
\hline \multirow{3}{*}{$\begin{array}{c}\text { Total } \\
\text { School/Church } \\
\text { Trips (in trip day) }\end{array}$} & Distance & 12.47 & 14.42 & $4.02^{*}$ & 17.84 & 19.40 & 1.73 \\
\hline & Duration & 32.12 & 33.43 & $2.07^{*}$ & 32.79 & 35.56 & $2.39^{*}$ \\
\hline & Frequency & 2.02 & 2.03 & 0.48 & 1.97 & 2.02 & 1.77 \\
\hline \multirow{3}{*}{$\begin{array}{c}\text { Total } \\
\text { Medical/Dentral } \\
\text { Trips (in trip day) } \\
\end{array}$} & Distance & 13.26 & 14.42 & 1.71 & 20.69 & 21.79 & 0.72 \\
\hline & Duration & 31.99 & 33.48 & 1.43 & 36.15 & 39.88 & 1.63 \\
\hline & Frequency & 1.69 & 1.70 & 0.2 & 1.67 & 1.67 & 0.09 \\
\hline \multirow{3}{*}{$\begin{array}{l}\text { Total Visit } \\
\text { Friends/Relatives } \\
\text { Trips (in trip day) }\end{array}$} & Distance & 30.99 & 30.31 & -0.49 & 33.89 & 32.48 & -0.67 \\
\hline & Duration & 49.22 & 46.72 & $-2.19^{*}$ & 48.56 & 48.81 & 0.13 \\
\hline & Frequency & 1.87 & 1.86 & -0.72 & 1.86 & 1.87 & 0.35 \\
\hline \multirow{3}{*}{$\begin{array}{l}\text { Total Other } \\
\text { Social/Recreational } \\
\text { Trips (in trip day) }\end{array}$} & Distance & 18.49 & 16.88 & $-3.36^{*}$ & 23.13 & 21.16 & $-2.14^{*}$ \\
\hline & Duration & 42.76 & 40.88 & $-3.69^{*}$ & 44.34 & 43.15 & -1.19 \\
\hline & Frequency & 2.13 & 2.22 & $7.67^{*}$ & 2.04 & 2.11 & $3.74^{*}$ \\
\hline
\end{tabular}


Appendix 2 Workers' One-way Commute Distance and Duration 2001 (Including and Excluding Occupation Variables)

\begin{tabular}{|c|c|c|c|c|c|c|c|c|}
\hline \multirow[b]{4}{*}{ Variables } & \multicolumn{4}{|c|}{ With Occupation Varibales } & \multicolumn{4}{|c|}{ Without Occupation Variables } \\
\hline & \multicolumn{2}{|c|}{ OLS 2001} & \multicolumn{2}{|c|}{ 2SLS 2001} & \multicolumn{2}{|c|}{ OLS 2001} & \multicolumn{2}{|c|}{ 2SLS 2001} \\
\hline & (1) & (2) & (3) & (4) & (5) & (6) & (7) & (8) \\
\hline & $\begin{array}{c}\text { Distance } \\
(\log )\end{array}$ & $\begin{array}{c}\text { Duration } \\
(\log )\end{array}$ & $\begin{array}{c}\text { Distance } \\
(\log )\end{array}$ & $\begin{array}{c}\text { Duration } \\
\text { (log) }\end{array}$ & $\begin{array}{c}\text { Distance } \\
(\log )\end{array}$ & $\begin{array}{c}\text { Duration } \\
(\log )\end{array}$ & $\begin{array}{c}\text { Distance } \\
(\log )\end{array}$ & $\begin{array}{l}\text { Duration } \\
\text { (log) }\end{array}$ \\
\hline Telecommuter (dummy) & $\begin{array}{l}0.019 \\
(1.05)\end{array}$ & $\begin{array}{l}0.016 \\
(1.07)\end{array}$ & $\begin{array}{c}1.549^{\star \star \star} \\
(5.68)\end{array}$ & $\begin{array}{c}0.571^{\star \star *} \\
(2.76)\end{array}$ & $\begin{array}{l}0.004 \\
(0.22)\end{array}$ & $\begin{array}{l}0.004 \\
(0.25)\end{array}$ & $\begin{array}{c}1.182^{\star \star \star} \\
(4.61)\end{array}$ & $\begin{array}{l}0.337^{*} \\
(1.70)\end{array}$ \\
\hline Age & $\begin{array}{c}-0.003^{* * *} \\
(-8.63)\end{array}$ & $\begin{array}{c}0.001^{\star * *} \\
(4.00)\end{array}$ & $\begin{array}{c}-0.004^{* * *} \\
(-9.57)\end{array}$ & $\begin{array}{l}0.001^{*} \\
(1.76)\end{array}$ & $\begin{array}{c}-0.002^{* * *} \\
(-7.23)\end{array}$ & $\begin{array}{c}0.001^{* * *} \\
(5.60)\end{array}$ & $\begin{array}{c}-0.003^{* * *} \\
(-7.99)\end{array}$ & $\begin{array}{c}0.001^{* * *} \\
(3.97)\end{array}$ \\
\hline Male & $\begin{array}{c}0.164^{\star \star \star} \\
(21.05)\end{array}$ & $\begin{array}{c}0.112^{\star * *} \\
(18.27)\end{array}$ & $\begin{array}{c}0.151^{\star \star \star} \\
(17.53)\end{array}$ & $\begin{array}{c}0.105^{\star \star \star} \\
(16.27)\end{array}$ & $\begin{array}{c}0.193^{* * *} \\
(26.75)\end{array}$ & $\begin{array}{c}0.127^{\star \star \star} \\
(22.37)\end{array}$ & $\begin{array}{c}0.183^{\star * *} \\
(23.70)\end{array}$ & $\begin{array}{c}0.121^{* * *} \\
(20.66)\end{array}$ \\
\hline Medical Condition & $\begin{array}{l}0.013 \\
(0.49)\end{array}$ & $\begin{array}{l}0.022 \\
(1.12)\end{array}$ & $\begin{array}{l}-0.051^{*} \\
(-1.72)\end{array}$ & $\begin{array}{l}-0.003 \\
(-0.11)\end{array}$ & $\begin{array}{l}0.013 \\
(0.53)\end{array}$ & $\begin{array}{l}0.024 \\
(1.18)\end{array}$ & $\begin{array}{l}-0.037 \\
(-1.27)\end{array}$ & $\begin{array}{l}0.007 \\
(0.32)\end{array}$ \\
\hline High Sch. Grad. Some College & $\begin{array}{c}0.229^{* * *} \\
(15.33)\end{array}$ & $\begin{array}{c}0.135^{\star \star \star} \\
(11.54)\end{array}$ & $\begin{array}{c}0.218^{\star \star *} \\
(13.10)\end{array}$ & $\begin{array}{c}0.132^{\star * \star *} \\
(10.61)\end{array}$ & $\begin{array}{c}0.251^{\star \star \star} \\
(16.92)\end{array}$ & $\begin{array}{c}0.156^{\star \star \star} \\
(13.40)\end{array}$ & $\begin{array}{c}0.250^{\star \star \star *} \\
(15.56)\end{array}$ & $\begin{array}{c}0.158^{\star \star *} \\
(12.95)\end{array}$ \\
\hline BA Degree & $\begin{array}{c}0.282^{* * *} \\
(17.23)\end{array}$ & $\begin{array}{c}0.182^{* * *} \\
(14.17)\end{array}$ & $\begin{array}{c}0.240^{* * *} \\
(12.17)\end{array}$ & $\begin{array}{c}0.168^{\star \star * *} \\
(11.35)\end{array}$ & $\begin{array}{c}0.325^{\star * *} \\
(20.60)\end{array}$ & $\begin{array}{c}0.221^{* * *} \\
(17.87)\end{array}$ & $\begin{array}{c}0.298^{* * *} \\
(16.15)\end{array}$ & $\begin{array}{c}0.216^{* * *} \\
(15.42)\end{array}$ \\
\hline Graduate Degree & $\begin{array}{c}0.208^{\star \star *} \\
(10.86)\end{array}$ & $\begin{array}{c}0.146^{\star \star \star} \\
(9.67)\end{array}$ & $\begin{array}{c}0.125^{\star \star \star} \\
(4.73)\end{array}$ & $\begin{array}{c}0.116^{\star \star \star *} \\
(5.86)\end{array}$ & $\begin{array}{c}0.276^{\star \star *} \\
(15.18)\end{array}$ & $\begin{array}{c}0.203^{\star \star *} \\
(14.28)\end{array}$ & $\begin{array}{c}0.217^{\star \star *} \\
(8.87)\end{array}$ & $\begin{array}{c}0.190^{\star * *} \\
(10.19)\end{array}$ \\
\hline Sales or Service & $\begin{array}{c}-0.200^{\star * *} \\
(-17.70)\end{array}$ & $\begin{array}{c}-0.149^{\star * *} \\
(-16.77)\end{array}$ & $\begin{array}{c}-0.247^{\star * *} \\
(-16.63)\end{array}$ & $\begin{array}{c}-0.166^{\star * *} \\
(-14.95)\end{array}$ & - & $\begin{array}{l}- \\
-\end{array}$ & $\begin{array}{l}- \\
-\end{array}$ & - \\
\hline $\begin{array}{l}\text { Clerical or administrative } \\
\text { support }\end{array}$ & $\begin{array}{c}-0.119^{\star \star *} \\
(-8.43)\end{array}$ & $\begin{array}{c}-0.056^{* * *} \\
(-5.01)\end{array}$ & $\begin{array}{c}-0.128^{* \star *} \\
(-8.25)\end{array}$ & $\begin{array}{c}-0.061^{\star * *} \\
(-5.24)\end{array}$ & - & $\begin{array}{l}- \\
-\end{array}$ & $\begin{array}{l}- \\
-\end{array}$ & - \\
\hline $\begin{array}{l}\text { Professional, managerial or } \\
\text { technical }\end{array}$ & $\begin{array}{c}-0.025^{\star *} \\
(-2.18)\end{array}$ & $\begin{array}{l}-0.004 \\
(-0.48)\end{array}$ & $\begin{array}{c}-0.049^{* \star *} \\
(-3.64)\end{array}$ & $\begin{array}{l}-0.012 \\
(-1.19)\end{array}$ & $\begin{array}{l}- \\
-\end{array}$ & $\begin{array}{l}- \\
-\end{array}$ & $\begin{array}{l}- \\
-\end{array}$ & $\begin{array}{l}- \\
-\end{array}$ \\
\hline Other occupation & $\begin{array}{l}-0.062 \\
(-1.11)\end{array}$ & $\begin{array}{l}-0.011 \\
(-0.26)\end{array}$ & $\begin{array}{l}-0.017 \\
(-0.29)\end{array}$ & $\begin{array}{l}0.012 \\
(0.27)\end{array}$ & - & - & - & - \\
\hline Household Income (log) & $\begin{array}{l}0.110^{* \star *} \\
(17.38)\end{array}$ & $\begin{array}{c}0.039^{* \star *} \\
(7.79)\end{array}$ & $\begin{array}{c}0.099^{* * *} \\
(13.86)\end{array}$ & $\begin{array}{c}0.034^{\star \star *} \\
(6.34)\end{array}$ & $\begin{array}{l}0.118^{\star * *} \\
(18.74)\end{array}$ & $\begin{array}{c}0.045^{* * *} \\
(9.19)\end{array}$ & $\begin{array}{l}0.109^{* * *} \\
(15.72)\end{array}$ & $\begin{array}{c}0.042^{* * *} \\
(7.98)\end{array}$ \\
\hline Child & $\begin{array}{l}0.025^{\star \star \star} \\
(3.23)\end{array}$ & $\begin{array}{l}0.015^{* *} \\
(2.55)\end{array}$ & $\begin{array}{l}0.014^{*} \\
(1.65)\end{array}$ & $\begin{array}{l}0.012^{*} \\
(1.94)\end{array}$ & $\begin{array}{l}0.031^{* * *} \\
(4.11)\end{array}$ & $\begin{array}{l}0.020^{\star \star *} \\
(3.39)\end{array}$ & $\begin{array}{l}0.024^{* * *} \\
(2.88)\end{array}$ & $\begin{array}{l}0.019^{* * *} \\
(3.03)\end{array}$ \\
\hline Num. of Vehicles per Driver & $\begin{array}{l}0.081^{* * *} \\
(10.49)\end{array}$ & $\begin{array}{c}0.036^{* * *} \\
(5.92)\end{array}$ & $\begin{array}{c}0.078^{* * *} \\
(9.23)\end{array}$ & $\begin{array}{c}0.035^{\star \star *} \\
(5.51)\end{array}$ & $\begin{array}{c}0.086^{* * *} \\
(11.10)\end{array}$ & $\begin{array}{c}0.039^{* * *} \\
(6.38)\end{array}$ & $\begin{array}{c}0.085^{\star \star *} \\
(10.29)\end{array}$ & $\begin{array}{c}0.039^{* * *} \\
(6.17)\end{array}$ \\
\hline Residence in Urbanized Area & $\begin{array}{c}-0.415^{\star \star \star} \\
(-44.87)\end{array}$ & $\begin{array}{l}-0.198^{\star \star \star} \\
(-27.21)\end{array}$ & $\begin{array}{l}-0.413^{\star * *} \\
(-40.94)\end{array}$ & $\begin{array}{l}-0.198^{\star \star \star} \\
(-26.08)\end{array}$ & $\begin{array}{c}-0.420^{* \star *} \\
(-45.30)\end{array}$ & $\begin{array}{l}-0.201^{\star * *} \\
(-27.55)\end{array}$ & $\begin{array}{l}-0.420^{\star * \star} \\
(-42.54)\end{array}$ & $\begin{array}{l}-0.202^{\star * \star} \\
(-26.79)\end{array}$ \\
\hline Residence in Rural Area & $\begin{array}{l}-0.037 \\
(-0.87)\end{array}$ & $\begin{array}{l}-0.035 \\
(-1.04)\end{array}$ & $\begin{array}{l}0.043 \\
(0.91)\end{array}$ & $\begin{array}{l}-0.007 \\
(-0.20)\end{array}$ & $\begin{array}{l}-0.032 \\
(-0.76)\end{array}$ & $\begin{array}{l}-0.032 \\
(-0.96)\end{array}$ & $\begin{array}{l}0.030 \\
(0.63)\end{array}$ & $\begin{array}{l}-0.017 \\
(-0.46)\end{array}$ \\
\hline Not in a MSA & $\begin{array}{l}-0.040 \\
(-0.97)\end{array}$ & $\begin{array}{l}0.012 \\
(0.37)\end{array}$ & $\begin{array}{c}-0.126^{* * *} \\
(-2.68)\end{array}$ & $\begin{array}{l}-0.018 \\
(-0.50)\end{array}$ & $\begin{array}{l}-0.047 \\
(-1.11)\end{array}$ & $\begin{array}{l}0.009 \\
(0.28)\end{array}$ & $\begin{array}{l}-0.114^{* *} \\
(-2.47)\end{array}$ & $\begin{array}{l}-0.009 \\
(-0.25)\end{array}$ \\
\hline In a MSA of $250,000-499,999$ & $\begin{array}{c}0.129^{* \star *} \\
(11.02)\end{array}$ & $\begin{array}{c}0.121^{\star * *} \\
(13.16)\end{array}$ & $\begin{array}{c}0.126^{* \star *} \\
(9.90)\end{array}$ & $\begin{array}{c}0.121^{* \star *} \\
(12.64)\end{array}$ & $\begin{array}{c}0.127^{\star * *} \\
(10.86)\end{array}$ & $\begin{array}{c}0.121^{\star \star \star} \\
(13.12)\end{array}$ & $\begin{array}{c}0.125^{\star \star \star} \\
(10.00)\end{array}$ & $\begin{array}{c}0.121^{* \star *} \\
(12.72)\end{array}$ \\
\hline In a MSA of $500,000-999,999$ & $\begin{array}{c}0.235^{\star \star *} \\
(16.44)\end{array}$ & $\begin{array}{c}0.269^{\star \star \star} \\
(23.91)\end{array}$ & $\begin{array}{c}0.230^{\star \star *} \\
(14.73)\end{array}$ & $\begin{array}{c}0.268^{* * *} \\
(22.86)\end{array}$ & $\begin{array}{c}0.229^{\star \star \star} \\
(16.02)\end{array}$ & $\begin{array}{c}0.266^{\star \star *} \\
(23.62)\end{array}$ & $\begin{array}{l}0.225^{\star * \star} \\
(14.76)\end{array}$ & $\begin{array}{c}0.266^{* * *} \\
(22.87)\end{array}$ \\
\hline In a MSA or CMSA of $1-2 m$ & $\begin{array}{c}0.288^{* * *} \\
(22.22)\end{array}$ & $\begin{array}{c}0.270^{\star * *} \\
(26.48)\end{array}$ & $\begin{array}{c}0.270^{* * *} \\
(18.76)\end{array}$ & $\begin{array}{c}0.266^{\star * *} \\
(24.64)\end{array}$ & $\begin{array}{c}0.283^{* \star *} \\
(21.74)\end{array}$ & $\begin{array}{c}0.267^{\star \star *} \\
(26.11)\end{array}$ & $\begin{array}{c}0.268^{* \star *} \\
(18.98)\end{array}$ & $\begin{array}{c}0.266^{\star * *} \\
(24.73)\end{array}$ \\
\hline In a MSA or CMSA over 3m & $\begin{array}{c}0.436^{\star \star \star *} \\
(37.98)\end{array}$ & $\begin{array}{c}0.455^{\star \star \star} \\
(50.46)\end{array}$ & $\begin{array}{c}0.417^{\star \star \star} \\
(32.38)\end{array}$ & $\begin{array}{c}0.449^{\star \star \star \star} \\
(46.41)\end{array}$ & $\begin{array}{c}0.430^{\star \star \star} \\
(37.33)\end{array}$ & $\begin{array}{c}0.451^{\star \star \star} \\
(49.97)\end{array}$ & $\begin{array}{c}0.415^{\star \star \star} \\
(32.81)\end{array}$ & $\begin{array}{c}0.449^{* * *} \\
(46.61)\end{array}$ \\
\hline Intercept & $\begin{array}{c}0.861^{* * *} \\
(12.49)\end{array}$ & $\begin{array}{c}2.123^{\star \star \star} \\
(39.47)\end{array}$ & $\begin{array}{c}1.043^{* \star *} \\
(12.71)\end{array}$ & $\begin{array}{c}2.194^{\star \star \star *} \\
(35.62)\end{array}$ & $\begin{array}{c}0.632^{\star \star \star} \\
(9.27)\end{array}$ & $\begin{array}{l}1.950^{\star \star \star} \\
(36.62)\end{array}$ & $\begin{array}{c}0.746^{* \star *} \\
(9.66)\end{array}$ & $\begin{array}{c}1.984^{\star \star *} \\
(33.76)\end{array}$ \\
\hline Observations & 58956 & 59317 & 55815 & 56158 & 58991 & 59358 & 55849 & 56198 \\
\hline R-squared & 0.093 & 0.085 & - & 0.062 & 0.086 & 0.078 & 0.022 & 0.070 \\
\hline
\end{tabular}

t-statistics in parentheses

${ }^{* \star *} p<0.01,{ }^{* *} p<0.05,{ }^{*} p<0.1$

1. In order to eliminate the endogeneity problem associated with transportation mode, sample is restricted to workers who use personal vehicles for commuting. Workers commuting by public transit or other modes are dropped. 
Appendix 3 Workers' One-way Commute Distance and Duration (2SGMM and 2SPLS models)

\begin{tabular}{|c|c|c|c|c|c|c|c|c|}
\hline & \multicolumn{2}{|c|}{ 2SGMM 2001} & \multicolumn{2}{|c|}{ 2SPLS 2001} & \multicolumn{2}{|c|}{ 2SGMM 2009} & \multicolumn{2}{|c|}{ 2SPLS 2009} \\
\hline & (9) & (10) & (11) & (12) & (13) & (14) & (15) & (16) \\
\hline Variables & $\begin{array}{c}\text { Distance } \\
(\log )\end{array}$ & $\begin{array}{c}\text { Duration } \\
(\log )\end{array}$ & $\begin{array}{c}\text { Distance } \\
(\log )\end{array}$ & $\begin{array}{c}\text { Duration } \\
(\log )\end{array}$ & $\begin{array}{c}\text { Distance } \\
(\log )\end{array}$ & $\begin{array}{l}\text { Duration } \\
\text { (log) }\end{array}$ & $\begin{array}{c}\text { Distance } \\
(\log )\end{array}$ & $\begin{array}{l}\text { Duration } \\
\text { (log) }\end{array}$ \\
\hline Telecommuting (dummy) & $\begin{array}{c}1.180^{\star \star \star} \\
(4.60)\end{array}$ & $\begin{array}{l}0.338^{*} \\
(1.71)\end{array}$ & $\begin{array}{c}0.766^{\star \star \star} \\
(3.72)\end{array}$ & $\begin{array}{l}0.297^{*} \\
(1.83)\end{array}$ & $\begin{array}{c}2.819^{\star \star *} \\
(6.40)\end{array}$ & $\begin{array}{c}0.993^{* \star \star} \\
(3.08)\end{array}$ & $\begin{array}{c}1.555^{\star \star \star \star} \\
(6.56)\end{array}$ & $\begin{array}{c}1.176^{* \star \star} \\
(6.24)\end{array}$ \\
\hline Age & $\begin{array}{c}-0.003^{\star * \star} \\
(-8.00)\end{array}$ & $\begin{array}{c}0.001^{* * *} \\
(3.96)\end{array}$ & $\begin{array}{c}-0.003^{\star * *} \\
(-7.72)\end{array}$ & $\begin{array}{c}0.001^{* * *} \\
(4.32)\end{array}$ & $\begin{array}{l}-0.004^{\star \star \star} \\
(-11.54)\end{array}$ & $\begin{array}{l}-0.000^{*} \\
(-1.68)\end{array}$ & $\begin{array}{c}-0.003^{\star * \star} \\
(-12.97)\end{array}$ & $\begin{array}{c}-0.001^{* * *} \\
(-2.73)\end{array}$ \\
\hline Male & $\begin{array}{c}0.183^{* \star *} \\
(23.72)\end{array}$ & $\begin{array}{c}0.121^{* * *} \\
(20.68)\end{array}$ & $\begin{array}{c}0.184^{* \star *} \\
(24.77)\end{array}$ & $\begin{array}{l}0.121^{* \star *} \\
(20.77)\end{array}$ & $\begin{array}{c}0.176^{\star \star \star} \\
(25.92)\end{array}$ & $\begin{array}{c}0.122^{* \star *} \\
(25.06)\end{array}$ & $\begin{array}{c}0.183^{\star \star \star} \\
(33.01)\end{array}$ & $\begin{array}{c}0.121^{* \star * *} \\
(27.29)\end{array}$ \\
\hline Medical Condition & $\begin{array}{l}-0.036 \\
(-1.21)\end{array}$ & $\begin{array}{l}0.007 \\
(0.32)\end{array}$ & $\begin{array}{l}-0.022 \\
(-0.79)\end{array}$ & $\begin{array}{l}0.008 \\
(0.39)\end{array}$ & $\begin{array}{c}-0.086^{* * *} \\
(-3.91)\end{array}$ & $\begin{array}{l}-0.016 \\
(-1.03)\end{array}$ & $\begin{array}{c}-0.067^{* * *} \\
(-3.88)\end{array}$ & $\begin{array}{l}-0.018 \\
(-1.29)\end{array}$ \\
\hline High Sch. Grad. Some College & $\begin{array}{c}0.250^{\star \star \star *} \\
(15.18)\end{array}$ & $\begin{array}{c}0.158^{\star \star * *} \\
(12.54)\end{array}$ & $\begin{array}{c}0.253^{\star \star *} \\
(16.40)\end{array}$ & $\begin{array}{c}0.158^{\star \star \star} \\
(13.08)\end{array}$ & $\begin{array}{c}0.094^{* * *} \\
(5.62)\end{array}$ & $\begin{array}{c}0.044^{* \star *} \\
(3.57)\end{array}$ & $\begin{array}{c}0.100^{* * *} \\
(6.74)\end{array}$ & $\begin{array}{c}0.044^{* * *} \\
(3.77)\end{array}$ \\
\hline BA Degree & $\begin{array}{c}0.299^{\star \star \star \star} \\
(15.95)\end{array}$ & $\begin{array}{c}0.217^{\star * * *} \\
(15.08)\end{array}$ & $\begin{array}{c}0.311^{* * *} \\
(17.94)\end{array}$ & $\begin{array}{c}0.217^{* \star \star} \\
(16.01)\end{array}$ & $\begin{array}{c}0.046^{* *} \\
(2.02)\end{array}$ & $\begin{array}{c}0.050^{\star \star \star *} \\
(3.04)\end{array}$ & $\begin{array}{c}0.087^{* \star *} \\
(5.03)\end{array}$ & $\begin{array}{c}0.045^{* * *} \\
(3.25)\end{array}$ \\
\hline Graduate Degree & $\begin{array}{c}0.218^{\star \star \star} \\
(8.80)\end{array}$ & $\begin{array}{c}0.190^{\star \star \star} \\
(10.08)\end{array}$ & $\begin{array}{c}0.241^{* * *} \\
(10.85)\end{array}$ & $\begin{array}{c}0.192^{\star \star \star} \\
(11.03)\end{array}$ & $\begin{array}{l}-0.042 \\
(-1.51)\end{array}$ & $\begin{array}{l}0.020 \\
(1.01)\end{array}$ & $\begin{array}{l}0.017 \\
(0.87)\end{array}$ & $\begin{array}{l}0.012 \\
(0.74)\end{array}$ \\
\hline Household Income (log) & $\begin{array}{c}0.109^{\star \star *} \\
(15.32)\end{array}$ & $\begin{array}{c}0.042^{* \star *} \\
(7.80)\end{array}$ & $\begin{array}{c}0.112^{\star \star *} \\
(16.90)\end{array}$ & $\begin{array}{c}0.043^{\star \star \star} \\
(8.23)\end{array}$ & $\begin{array}{c}0.094^{\star * *} \\
(10.88)\end{array}$ & $\begin{array}{c}0.054^{\star \star \star} \\
(8.68)\end{array}$ & $\begin{array}{c}0.114^{\star \star \star} \\
(19.77)\end{array}$ & $\begin{array}{c}0.052^{\text {***}} \\
(11.37)\end{array}$ \\
\hline Child & $\begin{array}{c}0.024^{\star \star \star \star} \\
(2.89)\end{array}$ & $\begin{array}{c}0.019^{* * *} \\
(3.02)\end{array}$ & $\begin{array}{c}0.026^{* \star *} \\
(3.23)\end{array}$ & $\begin{array}{c}0.019^{\star * * *} \\
(3.06)\end{array}$ & $\begin{array}{c}0.017^{* *} \\
(1.97)\end{array}$ & $\begin{array}{c}0.024^{* \star *} \\
(3.91)\end{array}$ & $\begin{array}{c}0.031^{* \star *} \\
(4.59)\end{array}$ & $\begin{array}{c}0.022^{* * *} \\
(4.15)\end{array}$ \\
\hline Num. of Vehicles per Driver & $\begin{array}{c}0.085^{\star \star *} \\
(9.91)\end{array}$ & $\begin{array}{c}0.039^{\star * * *} \\
(6.05)\end{array}$ & $\begin{array}{c}0.087^{\star \star *} \\
(10.83)\end{array}$ & $\begin{array}{c}0.039^{\star * \star} \\
(6.23)\end{array}$ & $\begin{array}{c}0.082^{\star * \star *} \\
(11.57)\end{array}$ & $\begin{array}{c}0.048^{* * *} \\
(9.79)\end{array}$ & $\begin{array}{c}0.084^{\star \star * *} \\
(14.76)\end{array}$ & $\begin{array}{c}0.047^{\star \star \star \star} \\
(10.25)\end{array}$ \\
\hline Residence in Urbanized Area & $\begin{array}{c}-0.421^{* * *} \\
(-43.26)\end{array}$ & $\begin{array}{c}-0.202^{\star * *} \\
(-26.84)\end{array}$ & $\begin{array}{c}-0.421^{* * *} \\
(-44.09)\end{array}$ & $\begin{array}{c}-0.202^{* * *} \\
(-26.91)\end{array}$ & $\begin{array}{c}-0.381^{* * *} \\
(-48.21)\end{array}$ & $\begin{array}{c}-0.199^{\star * \star} \\
(-35.87)\end{array}$ & $\begin{array}{c}-0.382^{* \star *} \\
(-55.96)\end{array}$ & $\begin{array}{c}-0.199^{\star \star *} \\
(-36.49)\end{array}$ \\
\hline Residence in Rural Area & $\begin{array}{l}0.029 \\
(0.58)\end{array}$ & $\begin{array}{l}-0.015 \\
(-0.40)\end{array}$ & $\begin{array}{l}0.005 \\
(0.11)\end{array}$ & $\begin{array}{l}-0.020 \\
(-0.56)\end{array}$ & $\begin{array}{l}-0.023 \\
(-0.77)\end{array}$ & $\begin{array}{c}-0.057^{* * *} \\
(-2.84)\end{array}$ & $\begin{array}{c}-0.044^{*} \\
(-1.92)\end{array}$ & $\begin{array}{c}-0.054^{\star \star *} \\
(-2.97)\end{array}$ \\
\hline Not in a MSA & $\begin{array}{l}-0.113^{\star *} \\
(-2.31)\end{array}$ & $\begin{array}{l}-0.010 \\
(-0.28)\end{array}$ & $\begin{array}{c}-0.088^{\star *} \\
(-2.01)\end{array}$ & $\begin{array}{l}-0.005 \\
(-0.16)\end{array}$ & $\begin{array}{l}-0.003 \\
(-0.12)\end{array}$ & $\begin{array}{l}0.008 \\
(0.42)\end{array}$ & $\begin{array}{l}0.019 \\
(0.85)\end{array}$ & $\begin{array}{l}0.005 \\
(0.30)\end{array}$ \\
\hline In a MSA of $250,000-499,999$ & $\begin{array}{c}0.125^{\star \star *} \\
(10.69)\end{array}$ & $\begin{array}{c}0.121^{\star \star \star} \\
(13.68)\end{array}$ & $\begin{array}{c}0.125^{\star \star *} \\
(10.40)\end{array}$ & $\begin{array}{c}0.121^{\star \star \star} \\
(12.79)\end{array}$ & $\begin{array}{c}0.172^{* \star *} \\
(13.09)\end{array}$ & $\begin{array}{c}0.129^{\star \star \star} \\
(13.84)\end{array}$ & $\begin{array}{c}0.173^{\star \star *} \\
(14.29)\end{array}$ & $\begin{array}{c}0.128^{\star \star \star} \\
(13.27)\end{array}$ \\
\hline In a MSA of $500,000-999,999$ & $\begin{array}{c}0.226^{* \star *} \\
(15.76)\end{array}$ & $\begin{array}{c}0.266^{\star * *} \\
(24.22)\end{array}$ & $\begin{array}{c}0.229^{\star \star *} \\
(15.52)\end{array}$ & $\begin{array}{c}0.267^{* * *} \\
(23.07)\end{array}$ & $\begin{array}{c}0.204^{* * *} \\
(16.94)\end{array}$ & $\begin{array}{c}0.176^{\star \star *} \\
(20.74)\end{array}$ & $\begin{array}{c}0.208^{\star \star *} \\
(18.66)\end{array}$ & $\begin{array}{c}0.175^{\star \star *} \\
(19.69)\end{array}$ \\
\hline In a MSA or CMSA of $1-2 m$ & $\begin{array}{c}0.268^{* * *} \\
(20.00)\end{array}$ & $\begin{array}{c}0.266^{\star \star *} \\
(26.05)\end{array}$ & $\begin{array}{c}0.273^{\star \star *} \\
(20.21)\end{array}$ & $\begin{array}{c}0.266^{\star \star * *} \\
(25.11)\end{array}$ & $\begin{array}{c}0.262^{\star \star *} \\
(22.23)\end{array}$ & $\begin{array}{c}0.229^{\star \star \star *} \\
(27.83)\end{array}$ & $\begin{array}{c}0.278^{* \star *} \\
(27.81)\end{array}$ & $\begin{array}{c}0.227^{\star \star \star *} \\
(28.52)\end{array}$ \\
\hline In a MSA or CMSA over $3 \mathrm{~m}$ & $\begin{array}{c}0.415^{\star \star \star \star} \\
(33.56)\end{array}$ & $\begin{array}{c}0.449^{\star \star *} \\
(48.04)\end{array}$ & $\begin{array}{c}0.420^{\star \star \star *} \\
(34.85)\end{array}$ & $\begin{array}{l}0.449^{* \star \star} \\
(47.49)\end{array}$ & $\begin{array}{c}0.312^{\star \star \star \star} \\
(22.74)\end{array}$ & $\begin{array}{c}0.348^{* \star *} \\
(36.11)\end{array}$ & $\begin{array}{c}0.339^{* \star *} \\
(32.30)\end{array}$ & $\begin{array}{c}0.344^{* * *} \\
(41.19)\end{array}$ \\
\hline Intercept & $\begin{array}{c}0.744^{* \star *} \\
(9.35)\end{array}$ & 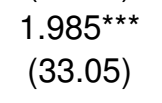 & $\begin{array}{c}0.702^{* * *} \\
(9.60)\end{array}$ & $\begin{array}{c}1.979^{\star \star *} \\
(34.68)\end{array}$ & $\begin{array}{l}1.183^{* * *} \\
(11.37)\end{array}$ & $\begin{array}{c}2.124^{* \star *} \\
(28.30)\end{array}$ & $\begin{array}{c}0.933^{* * *} \\
(13.73)\end{array}$ & $\begin{array}{c}2.153^{\star * \star} \\
(40.15)\end{array}$ \\
\hline Observations & 55849 & 56198 & 55849 & 56198 & 101007 & 101843 & 101007 & 101843 \\
\hline R-squared & 0.022 & 0.070 & 0.087 & 0.079 & - & - & 0.077 & 0.062 \\
\hline
\end{tabular}

t-statistics in parentheses

*** $p<0.01,{ }^{* *} p<0.05,{ }^{*} p<0.1$

1. For 2001 models that include occupation variables, see Appendix 2;

2. For education dummy variables, the reference is "less than high school";

3. For place of residence dummy variables, the reference is "residence in suburban area";

4. For MSA size dummy variables, the reference is "in an MSA of less than 250,000";

5. In order to eliminate the endogeneity problem associated with transportation mode, sample is restricted to workers who use personal vehicles for commuting. Workers commuting by public transit or other modes are dropped. 